\title{
Development of streamflow projections under changing climate conditions over Colorado River basin headwaters
}

\author{
W. P. Miller ${ }^{1,2}$, T. C. Piechota ${ }^{2,3}$, S. Gangopadhyay ${ }^{4}$, and T. Pruitt ${ }^{4}$ \\ ${ }^{1}$ United States Bureau of Reclamation, Lower Colorado Region, Boulder City, Nevada, USA \\ ${ }^{2}$ Department of Civil and Environmental Engineering, University of Nevada Las Vegas, Las Vegas, Nevada, USA \\ ${ }^{3}$ Associate Vice President for Interdisciplinary Research, Division of Research and Graduate Studies, \\ Office of the Urban Sustainability Initiative, University of Nevada Las Vegas, Las Vegas, Nevada, USA \\ ${ }^{4}$ Water Resources Planning and Operations Support Group, Technical Service Center, Bureau of Reclamation, \\ Denver, Colorado, USA
}

Received: 16 July 2010 - Published in Hydrol. Earth Syst. Sci. Discuss.: 12 August 2010

Revised: 25 March 2011 - Accepted: 3 July 2011 - Published: 13 July 2011

\begin{abstract}
The current drought over the Colorado River Basin has raised concerns that the US Department of the Interior, Bureau of Reclamation (Reclamation) may impose water shortages over the lower portion of the basin for the first time in history. The guidelines that determine levels of shortage are affected by relatively short-term (3 to 7 month) forecasts determined by the Colorado Basin River Forecast Center (CBRFC) using the National Weather Service (NWS) River Forecasting System (RFS) hydrologic model. While these forecasts by the CBRFC are useful, water managers within the basin are interested in long-term projections of streamflow, particularly under changing climate conditions. In this study, a bias-corrected, statistically downscaled dataset of projected climate is used to force the NWS RFS utilized by the CBRFC to derive projections of streamflow over the Green, Gunnison, and San Juan River headwater basins located within the Colorado River Basin. This study evaluates the impact of changing climate to evapotranspiration rates and contributes to a better understanding of how hydrologic processes change under varying climate conditions. The impact to evapotranspiration rates is taken into consideration and incorporated into the development of streamflow projections over Colorado River headwater basins in this study. Additionally, the NWS RFS is modified to account for impacts to evapotranspiration due to changing temperature over the basin. Adjusting evapotranspiration demands resulted in a $6 \%$ to $13 \%$ average decrease
\end{abstract}

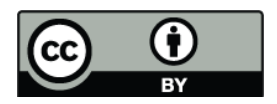

Correspondence to: W. P. Miller (wmiller@usbr.gov) in runoff over the Gunnison River Basin when compared to static evapotranspiration rates. Streamflow projections derived using projections of future climate and the NWS RFS provided by the CBRFC resulted in decreased runoff in 2 of the 3 basins considered. Over the Gunnison and San Juan River basins, a $10 \%$ to $15 \%$ average decrease in basin runoff is projected through the year 2099. However, over the Green River basin, a $5 \%$ to $8 \%$ increase in basin runoff is projected through 2099. Evidence of nonstationary behavior is apparent over the Gunnison and San Juan River basins.

\section{Introduction}

From 2000 through 2010, the Colorado River Basin has experienced the driest period on record and one the worst droughts in history (e.g, Timilsena et al., 2007). At the beginning of water year 1999 (October 1998), water storage in the Colorado River Basin was at $94 \%$ capacity; in particular, the two largest reservoirs within the system, Lake Powell and Lake Mead, were at $98 \%$ and $91 \%$ capacity, respectively. Since 1999, water storage in the Colorado River Basin has decreased to $55 \%$ capacity at the conclusion of 2010 with Lake Powell and Lake Mead at $40 \%$ and $59 \%$ capacity, respectively. The current drought has increased concerns on the ability of United States Department of the Interior, Bureau of Reclamation (Reclamation) to continue to meet water delivery requirements (Barnett and Pierce, 2008, 2009; Barsugli et al., 2009; Rajagopalan et al., 2009) and the impacts of climate change to hydroclimatology over the Colorado River Basin and the American West (e.g., Balling

Published by Copernicus Publications on behalf of the European Geosciences Union. 
Jr. and Goodrich, 2007; Brekke et al., 2008; Christensen and Lettenmaier, 2007; Fassnacht, 2006; Matter et al., 2010; Maurer, 2007; Meko et al., 2007; Miller and Piechota, 2008). Previous research indicates warming temperature trends over the Colorado River Basin region of up to $3{ }^{\circ} \mathrm{C}$ over the next 50 to $100 \mathrm{yr}$ (e.g., Christensen et al., 2004; Hoerling and Eischeid, 2007; McCabe and Wolock, 2008) and corresponding changes in the timing of streamflow within the basin, resulting in earlier peak runoff events (e.g., Christensen and Lettenmaier, 2007; Hamlet et al., 2005; Hamlet and Lettenmaier, 2007; Hidalgo et al., 2009; Kalra et al., 2008; Miller and Piechota, 2008; Regonda et al., 2005; Timilsena and Piechota, 2008).

Traditionally, Reclamation has used historical data to project future streamflow conditions and associated reservoir operations. Implicit in this practice is the assumption that the distribution of past data (e.g., mean, variance, standard deviation) is representative of future conditions. Under changing climate conditions, the past may no longer be representative of the future (e.g., Brekke et al., 2008). Climate change caused by anthropogenic influences has influenced global climate and hydrology such that past hydroclimatic means and extremes are no longer representative of expected hydroclimatology (Solomon et al., 2007). Milly et al. (2008) defines stationarity as the idea that natural systems fluctuate within an unchanging envelope of variability. As such, the assumption of hydroclimatic stationarity over the Colorado River Basin under climate change may not be correct.

Water managers have traditionally relied on the assumption of hydroclimatic stationarity to efficiently manage water resources and environmental operations. The timing and magnitude of runoff events is of particular importance, as actual and forecasted runoff events can impact the operation of reservoirs (e.g., release schedules and magnitudes); however, climate change and anthropogenic alterations to basin characteristics increase the difficulty in accurately projecting streamflow conditions within hydrologic systems (e.g., Villarini et al., 2009). Raff et al. (2009) developed a methodology to assess flood risk and runoff projections using projections of future climate. Raff et al. (2009) utilized temperature and precipitation data from 112 Global Climate Models (GCMs) within the World Climate Research Programme (WCRP) Coupled Model Intercomparison Project phase 3 (CMIP3) multi-model dataset (Meehl et al., 2007) subjected to statistical downscaling and bias-correction (Maurer et al., 2007) to drive the National Weather Service (NWS) River Forecasting System (RFS) hydrologic model. Each of the four basins investigated in Raff et al. (2009) exhibited the potential for increased flood frequency under changing climate conditions, although the authors did acknowledge the need for further study to more fully understand these results.

Other recent studies have developed alternative methodologies for incorporating temperature and precipitation patterns over the Upper Colorado River Basin (Matter et al., 2010). Christensen and Lettenmaier (2007) has previously used downscaled projections of precipitation and temperature to develop transient projections of runoff over the entire Colorado River Basin using the distributed Variable Infiltration and Capacity (VIC) model. Although this study does utilize information from the VIC model, the models and data sources presented in Raff et al. (2009) are more similar to those utilized here.

The development of a methodology to develop streamflow projections for use in river and reservoir management models is described. An important contribution of this work is the evaluation of the impacts of changing climate to evapotranspiration demand rates. The need to address evapotranspiration demand in climate studies over the Colorado River Basin has been documented by Brekke and Prairie (2009). The impact to evapotranspiration demands under changing temperature is taken into consideration and incorporated into the development of streamflow projections over Colorado River headwater basins. Here, 112 projections of future climate conditions over the Colorado River Basin are integrated with projections of future evapotranspiration to develop projections of streamflow conditions throughout the Gunnison, Green, and San Juan River headwater basins. Projections of streamflow are further investigated for evidence of nonstationary behavior.

\subsection{Study area}

The Colorado River Basin spans much of the American West, providing water to seven basin states and Mexico. The Colorado River provides water to over 27 million people and irrigates over $14000 \mathrm{~km}^{2}$ of farmland while generating over 8 billion kilowatt hours of hydroelectric power annually. The Colorado River Basin is divided between the supply-driven Upper Colorado River Basin and the demand-driven Lower Colorado River Basin; that is, water allocation in the Upper Colorado River Basin is dependent on available resources, whereas water is allocated based on demand in the Lower Colorado River Basin. Of the approximately 18500 million cubic-meters (MCM) of inflow into the Colorado River Basin, approximately $17900 \mathrm{MCM}$ is currently allocated annually. The Colorado River Basin is unique from other water management systems in that it has the capability to store approximately four times (74000 MCM) the average annual inflow; most of the storage is concentrated within the Lake Powell and Lake Mead reservoirs. Historically, inflow into the Colorado River Basin is highly variable and typically driven by snowpack in the Upper Colorado River Basin.

Projections of streamflow are developed over the Gunnison, Green, and San Juan River Basins (Fig. 1). Collectively, the three basins contribute nearly $66 \%$ of the average annual water year natural flow in the Upper Colorado River Basin. The basins in this study provide an opportunity to cover a broad latitudinal range of the Upper Colorado River Basin and compare results to other research efforts in the area. Each of these headwater basins have been subject to 


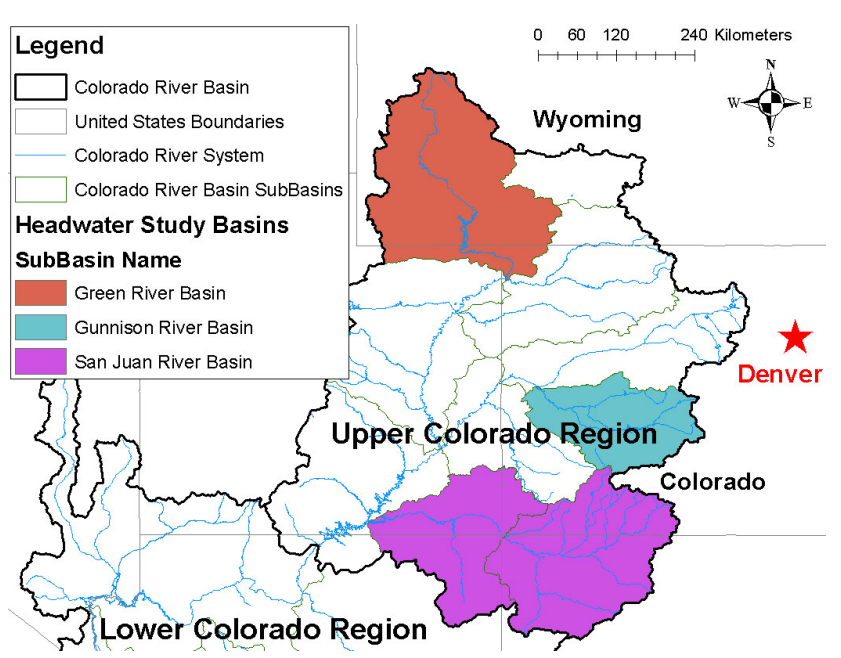

Fig. 1. The Colorado River Headwater Basins considered in this study encompass a broad range of the Upper Colorado River Basin. For reference, the city of Denver, Colorado is located at $39^{\circ} 44^{\prime} 21^{\prime \prime} \mathrm{N}, 104^{\circ} 59^{\prime} 5^{\prime \prime} \mathrm{W}$.

previous study and are accompanied by significant and interesting water issues. The Gunnison River Basin has been the subject of numerous studies, particularly for the application of downscaled climate projections (e.g., Brekke and Prairie, 2009; McCabe Jr., 1994; Raff et al., 2009; US Department of the Interior, Bureau of Reclamation, Upper Colorado Region, 2009). Research on the impacts of teleconnection events on drought and streamflow conditions in the Green River Basin have provided some insight as to the role of teleconnections to climate variability over the Colorado River Basin (Tootle and Piechota, 2003). The San Juan River Basin is an example of a water management agency actively working with stakeholders to adaptively manage a reservoir system in response to changing environmental and anthropogenic needs. Pursuant to the National Environmental Protection Act of 1969, an Environmental Impact Statement and Record of Decision were published in 2006 defining the operations of the Navajo Reservoir within the San Juan River Basin to aid in the conservation of endangered fish species, habitat, and continue to meet Reclamation's obligations to water delivery requirements and Native American water rights (US Department of the Interior, Bureau of Reclamation, Upper Colorado Region, 2006).

\subsection{Bias corrected spatially downscaled precipitation and temperature data}

Reclamation, in cooperation with Lawrence Livermore National Labs and Santa Clara University, has made available Bias Corrected Spatial Downscaled (BCSD) precipitation and temperature data from the WCRP CMIP3 dataset over the continental United States (available at: http://gdo-dcp. ucllnl.org/downscaled_cmip3_projections/ and referenced as
BCSD CMIP3 herein) (Maurer et al., 2007). The BCSD CMIP3 dataset utilized in this study considers three emissions scenarios (A2, A1B, and B1) as described in the Special Report on Emissions Scenarios produced by the Intergovernmental Panel on Climate Change (Nakićenović et al., 2000). This climate data has been downscaled to $1 / 8$ th degree (approximately 12 kilometers or 7.5 miles) grid cell resolution, making it more useful for regional hydrologic analysis. This data have been downscaled using the BCSD technique described in Wood et al. (2004) and is available at a monthly timestep. The method is documented in numerous peerreviewed academic studies (Cayan et al., 2007; Christensen et al., 2004; Hayhoe et al., 2004, 2007; Maurer and Duffy, 2005; Maurer, 2007; Payne et al., 2004; VanRheenen et al., 2004; Wood et al., 2004) and produces downscaled temperature and precipitation data that statistically matches the historical period. Brekke and Prairie (2009) previously applied monthly BCSD CMIP3 climate data over the Gunnison River Basin to generate projections of streamflow through 2099. Brekke and Prairie (2009) note that mean annual runoff is consistent throughout the 21 st century, but explain that these flows may be overestimated, as changes to potential evapotranspiration demand in response to future warming were not accounted for.

Reclamation is developing streamflow projections over the Upper Colorado River Basin using the VIC model and the BCSD CMIP3 dataset described in this study for the Colorado River Basin Water Supply and Demand Study (Basin Study) to examine the impacts of changing water supply and demand conditions over the Colorado River Basin (US Department of the Interior, Bureau of Reclamation, Lower Colorado Region, 2009). The VIC model is run at a daily timestep; as such, temporal disaggregation of data from the monthly BCSD CMIP3 dataset over the Colorado River Basin is required. Temporal disaggregation of the monthly BCSD CMIP3 data was accomplished by scaling historical daily precipitation or shifting historical daily temperature data to match monthly time series data (Wood et al., 2004). Daily precipitation and temperature time series have been derived for the entire spatial and temporal extent of the monthly BCSD CMIP3 dataset ${ }^{1}$.

\section{Methodology}

\subsection{Hydrologic model}

Reclamation is required to use streamflow forecasts by the CBRFC for input into operational and policy models. Streamflow forecasts developed by the CBRFC have the potential to significantly impact reservoir operations over

1 This data is archived at the Department of Energy (DOE) National Energy Research Scientific Computing (NERSC) Center. This data was prepared and is made available by Andy Wood of the CBRFC (andy.wood@noaa.gov). 
the Colorado River Basin. The CBRFC develops these streamflow forecasts through use of the NWS RFS (National Oceanic and Atmospheric Administration, National Weather Service, 2005) applied over the Colorado River Basin. The NWS RFS incorporates numerous models to develop unregulated inflow forecasts. The primary models within the RFS and utilized over the Colorado River Basin are the Sacramento Soil Moisture Accounting (SAC-SMA) model (Burnash et al., 1973) and the Snow Accumulation and Ablation Model (SNOW-17) (Anderson, 1973, 2006).

The NWS RFS model used here was provided by the CBRFC and is run without taking into account regulation; that is, the model is run without accounting for reservoir operations or diversions within a basin. This allows for an assessment of climate impacts to streamflow with limited anthropogenic influence. The NWS RFS provided by the CBRFC has been calibrated to observed streamflow within the Colorado River Basin. This calibration is thus dependent on historical climate input developed by the CBRFC. Aside from input files associated with temperature, precipitation, and evapotranspiration demand, the NWS RFS provided by the CBRFC is otherwise unchanged in this study.

The NWS RFS is a lumped hydrologic modeling system. Basins within the Colorado River Basin are divided into catchments that may each be solved individually using the NWS RFS. Each catchment may then be divided into up to three elevation bands. These elevation bands are unique to each catchment and are derived by the CBRFC; it is important to note that the SAC-SMA model within the NWS RFS is limited to three elevation bands per catchment, though some catchments rely on only one or two elevation bands. Headwater catchment input is primarily temperature and precipitation through the MAT and MAP input files. Catchments that are downstream from headwater and other catchments, described as "local" catchments, incorporate runoff from headwater catchments and other upstream local catchments in addition to precipitation and temperature input.

The NWS RFS incorporates mean areal temperature (MAT) and mean areal precipitation (MAP) input files. Over the water year 1976 through water year 2005 calibration period, the CBRFC derives these files through the use of gage measurements provided by a variety of sources (e.g., National Oceanic and Atmospheric Administration, National Resource Conservation Service, National Climatic Data Center, United States Geological Survey (USGS), and Reclamation). In this study, MAT and MAP files are developed using temporally disaggregated climate data from the BCSD CMIP3 dataset.

The NWS RFS provided by the CBRFC relies on values of evapotranspiration demand unique to each month; that is, evapotranspiration demand in any given month is identical throughout the length of the model run. For example, over a two-year model run, evapotranspiration demand for the month of January will be identical in both years; however, this evapotranspiration demand may vary month to month.

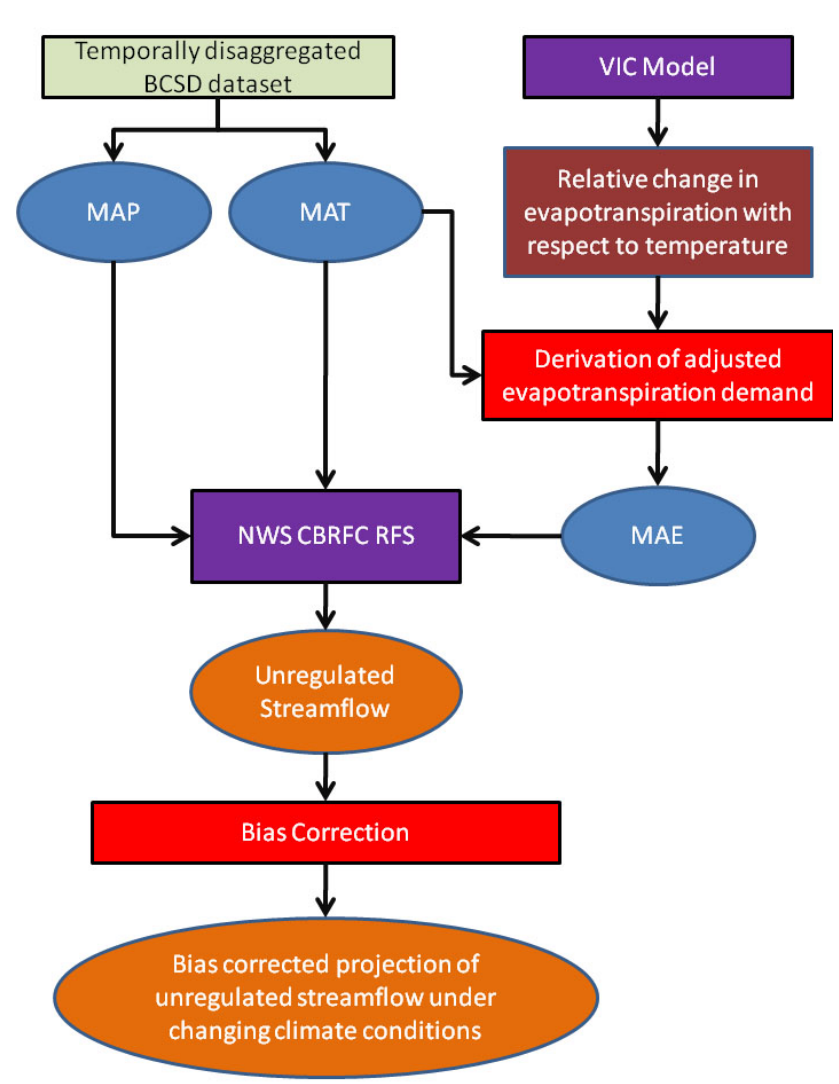

Fig. 2. This flow chart illustrates how the NWS CBRFC RFS and VIC model are utilized with multiple climate datasets to derive projections of streamflow.

In this study, evapotranspiration is derived as a function of monthly average projected temperature. As such, a third input file describing mean areal evapotranspiration (MAE) was developed in this study. Figure 2 illustrates how these models and data sets were developed and integrated to produce the projections of unregulated streamflow presented in this study.

\subsection{Derivation of MAT input files}

The NWS RFS requires temperature input at a 6-h timestep. The CBRFC derives 6-hourly temperature values using an empirical relationship between daily maximum and minimum temperature values. This practice is common between river forecasting centers, though the empirical relationship is unique to each river forecasting center. Empirical relationships are applied over all years and all seasons. For the CBRFC, the empirical relationships derived over the Colorado River Basin are as follows:

$$
\begin{aligned}
& 00 Z=0.950 \times T_{\min }+0.050 \times T_{\max -1} \\
& 06 Z=0.400 \times T_{\min }+0.600 \times T_{\max } \\
& 12 Z=0.025 \times T_{\min }+0.925 \times T_{\max }
\end{aligned}
$$


$18 Z=0.670 \times T_{\min }+0.330 \times T_{\max }$

where $Z$ denotes Coordinated Universal Time (UTC, sometimes referred to as Zulu time), $T_{\min }$ is the minimum daily recorded temperature, $T_{\max }$ is the maximum daily recorded temperature, and $T_{\max -1}$ is the previous day's maximum recorded temperature (Smith, 2009). Because of the empirical nature of these equations, it should be noted that under climate change, there is uncertainty as to how valid these equations are for long-term forecasting.

For each elevation band within the study area, a daily time series of minimum and maximum temperature data was derived by taking the average of daily minimum and maximum temperature values from each $1 / 8$ th degree grid cell from the temporally downscaled BCSD CMIP3 dataset. By applying the empirical formulations described in Eq. (1), a time series of 6-hourly temperature values was derived for each elevation band within each catchment. A MAT file containing this information for each elevation band within each catchment for each of the 112 climate projections is used as input for the NWS RFS.

\subsection{Derivation of MAP input files}

Similar to temperature data, the NWS RFS requires precipitation input at a 6-h timestep. Precipitation data was separated by elevation band and catchment using a method identical to that used to separate $1 / 8$ th degree temperature data. Unlike temperature data, the CBRFC currently uses observations of precipitation at the 6-hourly timestep and there are no empirical formulations to translate daily precipitation values to a 6-hourly timestep.

Time series of precipitation at a 6-h timestep were derived by first comparing the daily rainfall depth from the temporally disaggregated BCSD CMIP3 dataset to the 30-yr calibration period (1976-2005) of aggregated daily observations of precipitation used by the CBRFC. An analog precipitation event occurring in the same month from the temporally disaggregated BCSD CMIP3 dataset was then identified. The daily precipitation value from the temporally disaggregated BCSD CMIP3 dataset was then disaggregated to a 6-hourly time step proportional to the analog event within the CBRFC observed dataset. A MAP file containing this information for each elevation band within each catchment for each of the 112 climate projections is used as input for the NWS RFS.

\subsection{Derivation evapotranspiration demand rate of change with respect to temperature}

Evapotranspiration within the VIC model has been extensively studied (e.g., Christensen and Lettenmaier, 2007; Hamlet et al., 2007; Hurkmans et al., 2008, 2009; Lakshmi and Wood, 1998; Nijssen et al., 1997). Of particular importance to this study Hamlet et al. (2007), indicated that evapotranspiration trends within VIC were driven by trends in precipitation and temperature; concurrent work indicated that evapotranspiration significantly influenced projected streamflow response within the VIC model (Christensen and Lettenmaier, 2007). An advantage of the VIC model, and other hydrologic models discussed, over the NWS RFS utilized by the CBRFC is that these models allow for the user to account for evapotranspiration as a function of changing conditions within the model. The rate of change of evapotranspiration demand with respect to temperature over the Colorado River Basin at 1/8th degree resolution was derived through use of the VIC model. These average monthly rates of evapotranspiration demand change per degree temperature change derived through the VIC model were used to derive projected evapotranspiration demand over the study area. The VIC model computes evapotranspiration through use of the Penman-Montéith equation to estimate evapotranspiration.

Evapotranspiration demand rates were derived by increasing the minimum and maximum daily temperature within the VIC model by $1{ }^{\circ} \mathrm{C}$ and computing the relative change in evapotranspiration demand in the model. That is:

$\mathrm{ET}_{R}=\frac{\left(\mathrm{ET}_{1}-\mathrm{ET}_{0}\right)}{\mathrm{ET}_{0}}$

where $\mathrm{ET}_{R}$ is a ratio representing change in evapotranspiration demand per degree Celsius. ET $_{1}$ is the evapotranspiration demand rate calculated within the VIC model after the increase in temperature, and $\mathrm{ET}_{o}$ is the original evapotranspiration demand prior to the change in temperature parameters. Results were then averaged over a monthly timestep. It is important to note that only the rate of change in evapotranspiration with respect to temperature is further utilized from the VIC model in this study; the magnitude of evapotranspiration demand as defined by the VIC model is only used in this study to derive this rate of change.

\subsection{Derivation of MAE Input Files}

Daily evapotranspiration data was derived by first averaging the rate of evapotranspiration change per 1 degree Celsius derived through the use of the VIC model over each elevation band within the study area for each month over the 30-yr calibration period. In addition, 12 base average temperatures were derived for each month for each of the 112 climate scenarios over the 30-yr calibration (1976-2005) period.

Historical (1976-2005) evapotranspiration demand within the NWS RFS model was used as a base evapotranspiration value. For each month over the model run (1950-2099), an average monthly temperature was derived. This monthly average temperature was then compared to the base temperature derived over the same month over the 30 -yr calibration period (1976-2005). The original evapotranspiration value was then adjusted based on the difference between average monthly temperature and the base monthly temperature:

$\mathrm{ET}_{t}=\mathrm{ET}_{\text {orig }}+\left(T_{t}-T_{\text {base }}\right) \times \overline{\mathrm{ET}_{R}}$

where $\mathrm{ET}_{t}$ is the adjusted monthly evapotranspiration demand at a given time, $\mathrm{ET}_{\text {orig }}$ is the historical 
evapotranspiration demand, $T_{t}$ is the average temperature over any given month in the derived time series, $T_{\text {base }}$ is the 30-yr calibration period average temperature for any given month, and $\overline{\mathrm{ET}_{R}}$ is the average $\mathrm{ET}_{R}$ over each elevation band as derived through use of the VIC model.

Daily evapotranspiration demand was assumed to be constant and uniform over the course of any given month. A MAE file containing this information for each elevation band within each catchment for each of the 112 climate projections is used as input for the NWS RFS.

\subsection{Post-run bias correction}

A ratio method was used to adjust streamflow projections such that the long term mean over the CBRFC calibration period (1976-2005) is equal to the long term mean derived through the use of the temporally disaggregated BCSD CMIP3 dataset over the same calibration period.

Average monthly streamflow projections over the 30-yr calibration period (1976-2005) were derived using streamflow output from the calibrated NWS RFS forced with historical precipitation and temperature data provided by the CBRFC. Additionally, average monthly streamflow projections for each of the 112 climate scenarios over the $30-\mathrm{yr}$ calibration period were derived using data from the temporally disaggregated BCSD CMIP3 dataset. The ratio of these two values was computed and applied to streamflow projections over the entire period of record (1950 through 2099) derived using the temporally disaggregated BCSD CMIP3 dataset. This result ensures that the derived long-term (30-yr) mean streamflow from 1976 through 2005 is equal between the original dataset provided by the CBRFC and the BCSD CMIP3 dataset.

\subsection{Model performance}

The NWS RFS model is calibrated to observed unregulated streamflow spanning water year 1976 through water year 2005; this calibration has been derived by the CBRFC using observed precipitation and temperature records and performs well. The correlation coefficient between observed unregulated flow and modeled unregulated flow using the calibrated model over the Gunnison River Basin was found to be approximately 0.98 with a root mean square error (RMSE) of approximately $47 \mathrm{MCM}$ (0.038 MAF) (Fig. 3). For the San Juan and Green River Basins, correlation coefficients of 0.98 and 0.85 and RMSEs of $45 \mathrm{MCM}(0.037 \mathrm{MAF})$ and $478 \mathrm{MCM}(0.39 \mathrm{MAF})$, respectively.

Because calibration of the NWS RFS over these three Colorado River headwater basins was accomplished using observations of historical temperature and precipitation data, the post-bias correction method described in the previous section was employed to adjust for bias introduced through use of the BCSD climate dataset. In doing so, the seasonal distribution and average magnitude of flow was preserved. Figure 4
Table 1. Statistics of streamflow projections pre- and post-bias correction. Values are presented in MCM.

\begin{tabular}{lrrr}
\hline & $\begin{array}{r}\text { Average of } \\
\text { CBRFC } \\
\text { Streamflow } \\
\text { Projection } \\
\text { 112 climate } \\
\text { projections }\end{array}$ & $\begin{array}{r}\text { Average of } \\
112 \text { climate } \\
\text { projections } \\
(1976-2005) \\
(1976-2005) \\
\text { pre-bias }\end{array}$ & $\begin{array}{r}\text { post-bias } \\
\text { correction }\end{array}$ \\
\hline correction & & 2230 & 2690 \\
Average median & 2690 & 2120 & 2530 \\
Average standard deviation & 2670 & 780 & 1050 \\
Average variance & 1000 & 510 & 910 \\
Average maximum & 810 & 4190 & 5410 \\
Average minimum & 4850 & 1000 & 1130 \\
Average skew & 860 & 870 & 1010 \\
\hline
\end{tabular}

illustrates the impacts of bias correction to the seasonal distribution of streamflow and improvement over the calibration period over the Gunnison River Basin. Figure 5 describes the impacts of bias correction to the spread of annual water year observations over the calibration period over the Gunnison River Basin. Bias correction impacts to monthly and annual distributions of streamflow are similar over the San Juan and Green River Basins. Calibration of the developed streamflow traces is not done on an annual basis; nor is modeled data calibrated to observed streamflow identically. As this study is investigating long-term impacts to headwater basins due to climate change, calibration efforts are focused on long-term averages (Table 1).

\section{Results of RFS model runs}

\subsection{Impact of evapotranspiration incorporation}

Figure 6 illustrates the impact of taking into account climate change impacts to evapotranspiration demand. Whereas the 10th and 90th percentiles over the $90 \mathrm{yr}$ projection period are approximately equal, the mean of the 112 climate projections is different. Over the 2010-2039 time period, adjusting evapotranspiration in response to temperature change results in a decrease of approximately 149 MCM (121 000 acre-feet or approximately $6 \%$ ) to the mean annual runoff than projections of mean annual runoff made without an adjustment to temperature. This difference increases over time, with a decrease of approximately $258 \mathrm{MCM}$ (209000 acre-feet or approximately $10 \%)$ and approximately $329 \mathrm{MCM}(267000$ acre-feet or approximately 13\%) over the 2040-2069 and 2070-2099 time periods, respectively.

Evapotranspiration demand and associated impacts to projections of streamflow over the Gunnison River Basin is spatially distributed (Fig. 7). Adjusting evapotranspiration demand with changing temperature impacts the Gunnison River Basin across all catchments, particularly those in the southern portion of the basin which is typically characterized by 


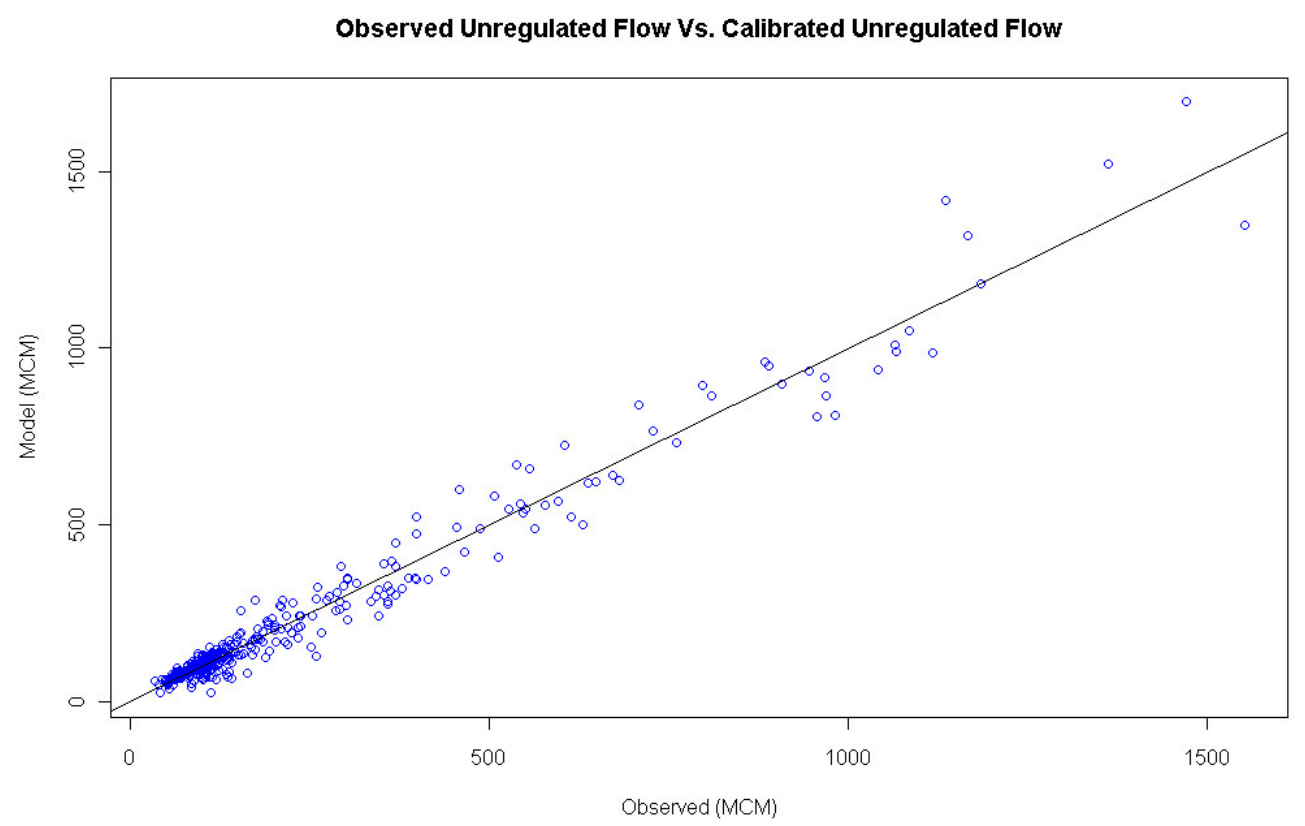

Fig. 3. The NWS RFS model is calibrated to observed unregulated streamflow spanning water years 1976-2005. Here, observed unregulated streamflow over the Gunnison River Basin is compared to modeled unregulated streamflow derived using observations of precipitation and temperature data.

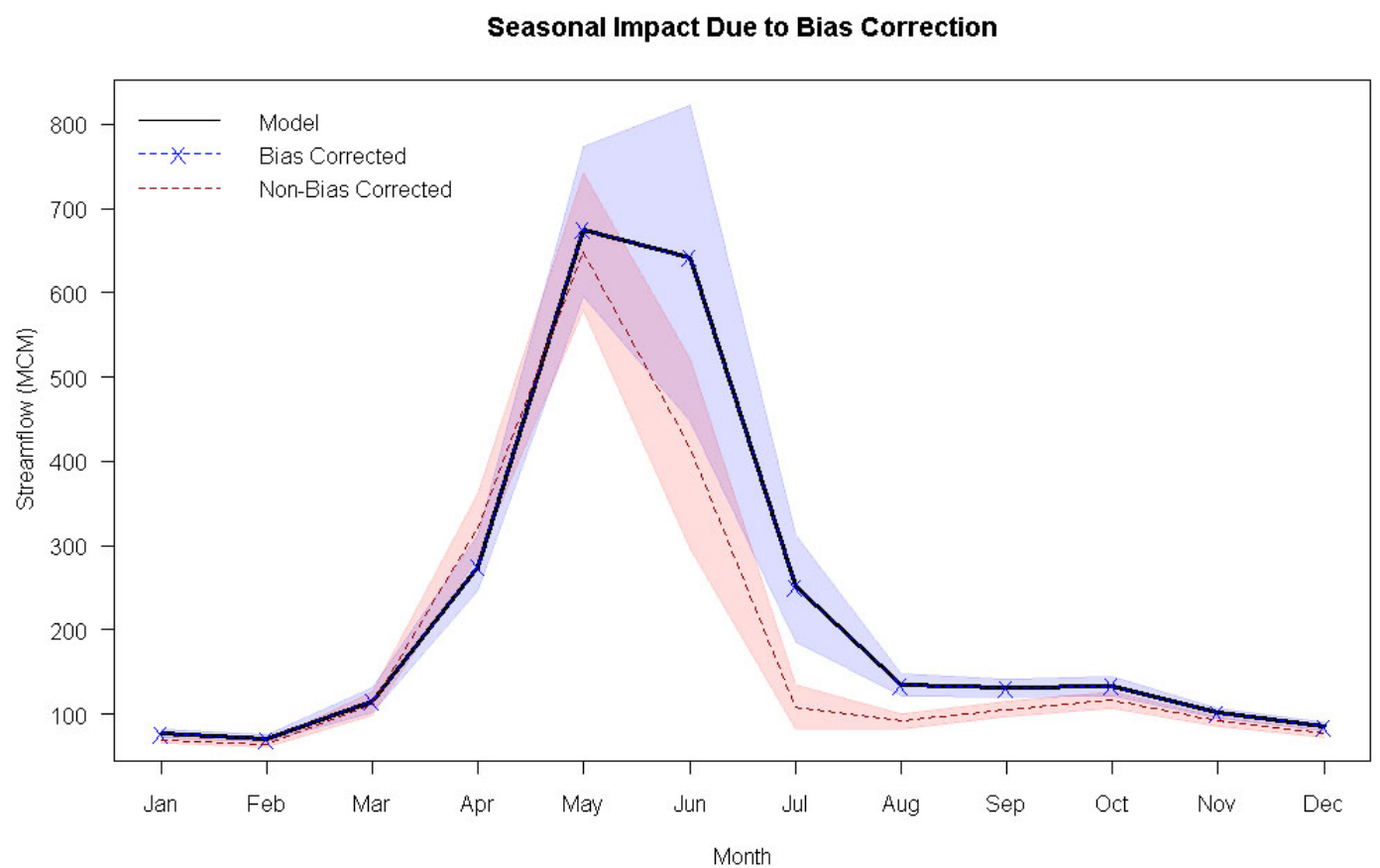

Fig. 4. The solid black line describes average monthly streamflow from the calibrated NWS RFS model forced with observed precipitation and temperature data over the calibration period (Water Year 1976 through Water Year 2005). The dashed red line describes average monthly streamflow from the calibrated NWS RFS model forced with projections of future climate from the BCSD dataset and adjusted evapotranspiration data; the surrounding red band describes the minimum and maximum monthly flows output by the model over the calibration period. The dashed blue line, which overlays the solid black line, and surrounding band illustrates the impact of the post-bias correction procedure to the data described in red. 
Water Year Impacts Due to Bias Correction (1976-2005)

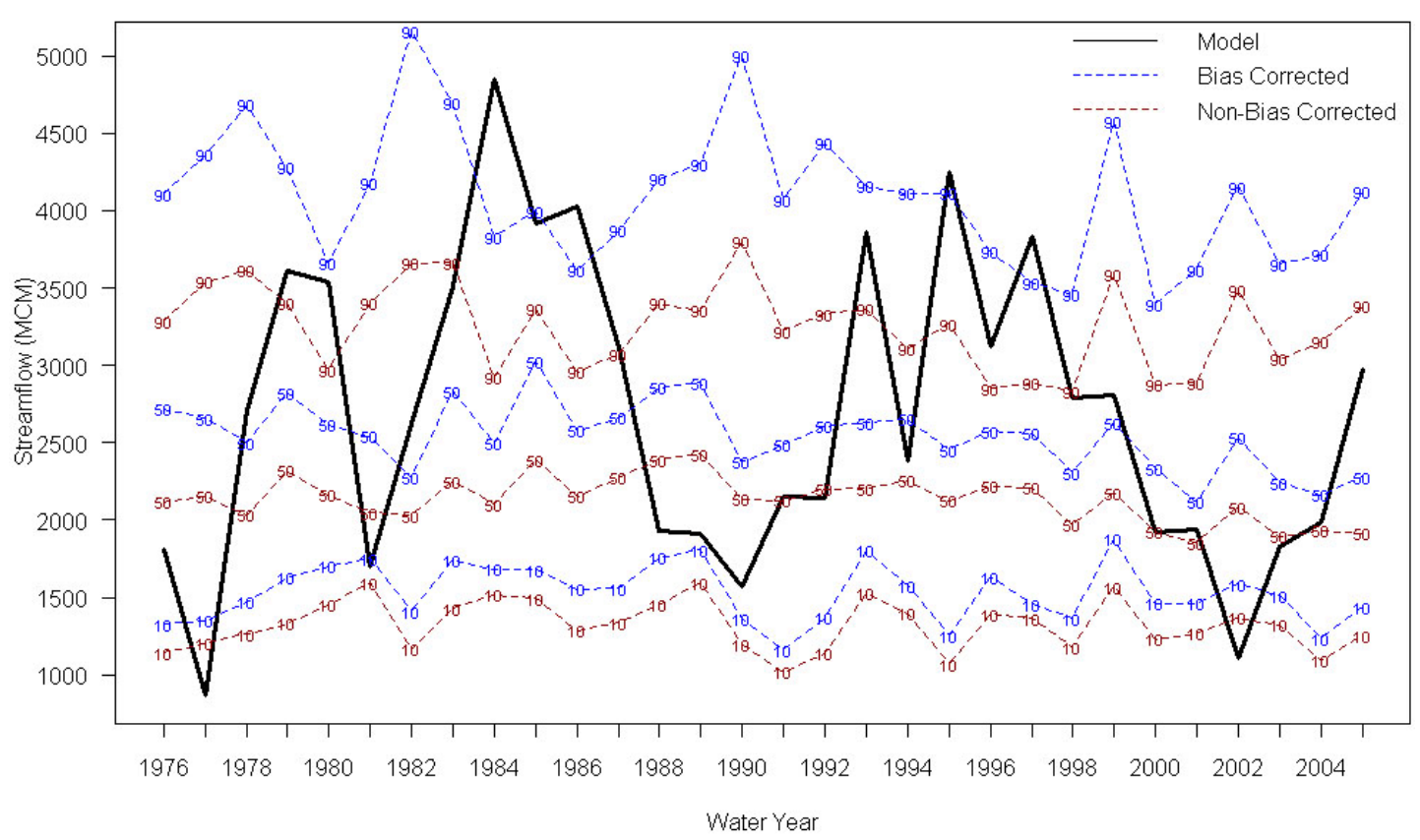

Fig. 5. The solid black line illustrates modeled water year streamflow over the Gunnison River Basin over the calibration period (1976-2005) when the calibrated RFS is forced with observed temperature and precipitation data. The dashed red line describes the 10th, 50th, and 90th percentiles of modeled streamflow using the 112 projections of future climate to force the RFS for any given water year over the calibration period. The dashed blue line illustrates the impact of post-bias correction to those modeled projections of streamflow.

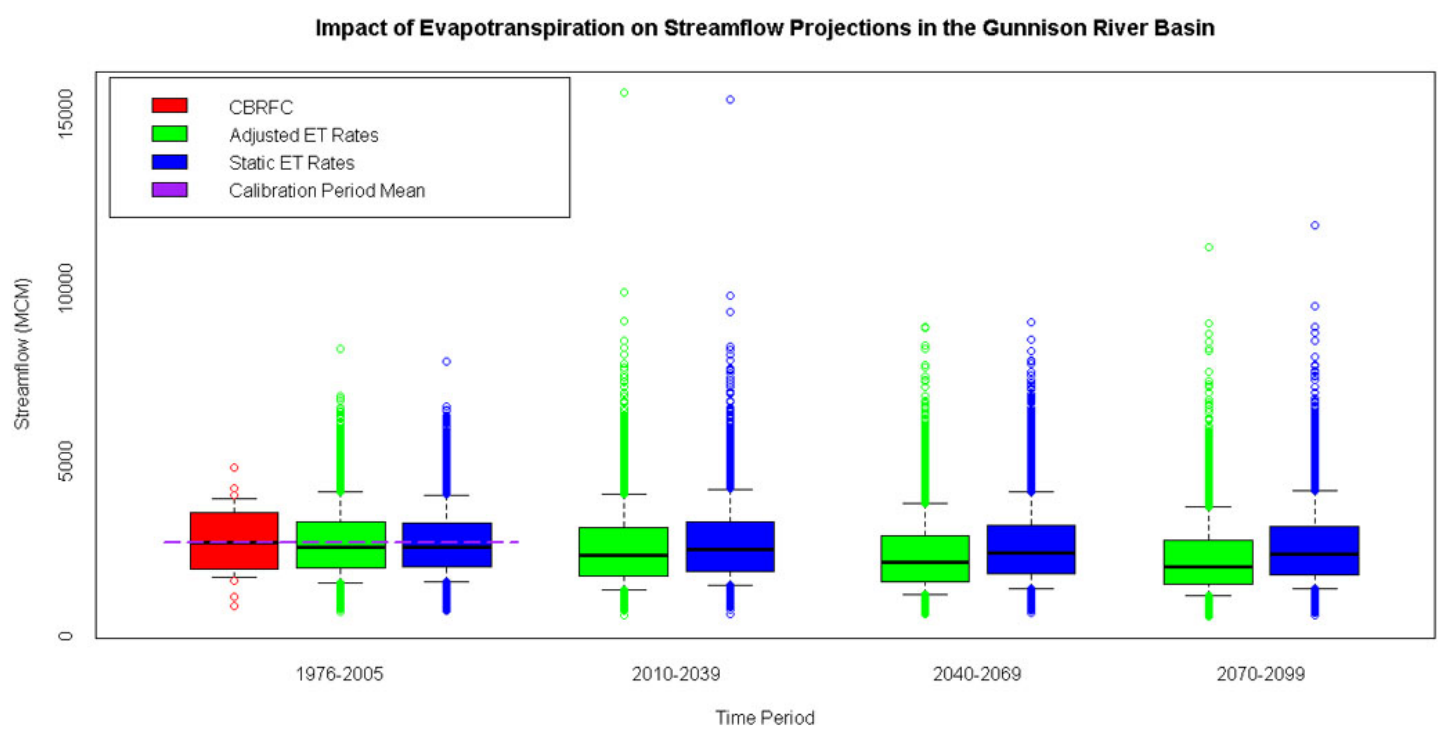

Fig. 6. Boxplots illustrating the impact of incorporating climate change impacts to evapotranspiration rates in the Gunnison River Basin. Boxplots in this study define the outer whiskers at the $10 \%$ and $90 \%$ exceedance values and the bounds of the box at the $25 \%$ and $75 \%$ exceedance values. The red boxplot illustrates results derived using data from the CBRFC over the calibration period. Green boxplots illustrate results derived using the temporally downscaled BCSD dataset and adjusting evapotranspiration in response to temperature change. Blue boxplots illustrate results derived using the temporally downscaled BCSD dataset without adjusting evapotranspiration in response to temperature change. 
Table 2. Average streamflow projections from the Gunnison River Basin. Projections are separated by SRES emissions scenarios and future multi-decadal periods.

\begin{tabular}{lcccc}
\hline \multicolumn{5}{c}{$\begin{array}{c}\text { Average streamflow projection (MCM) } \\
\text { from the Gunnison River Basin }\end{array}$} \\
\hline Time period & All & A2 & B1 & A1B \\
$2010-2039$ & 2550 & 2590 & 2580 & 2490 \\
$2040-2069$ & 2360 & 2330 & 2370 & 2370 \\
$2070-2099$ & 2260 & 2170 & 2340 & 2250 \\
\hline
\end{tabular}

flatter topography and contributes less flow to the Gunnison River tributary.

Streamflow projections are derived for each of the three headwater basins with evapotranspiration adjusted for temperature changes. Recent studies of climate change impacts to streamflow over the Colorado River Basin typically indicate decreasing flow within the basin between $10 \%$ and $20 \%$ (e.g., Barnett and Pierce, 2009. Christensen and Lettenmaier, 2007. Hamlet et al., 2007. Hoerling and Eischeid, 2007). When evapotranspiration demand is taken into consideration, these results support those findings.

\subsection{Streamflow projections}

\subsubsection{Gunnison River Basin}

The Gunnison River Basin contributes approximately $16 \%$ of the Upper Colorado River Basin's annual natural flow to the Colorado River. Over the 30-yr calibration period, the average runoff from the Gunnison is approximately $2690 \mathrm{MCM}$ (2.18 MAF). Each of the 112 climate projections was used to force the NWS RFS (Fig. 12). Over the model run period (1950-2099), average streamflow from the Gunnison River Basin is approximately $2530 \mathrm{MCM}$ (2.05 MAF). Table 2 summarizes the results of the streamflow projections over the Gunnison River Basin. Reclamation operates the Blue Mesa, Morrow Point, and Crystal Dams and Reservoirs, collectively known as the Aspinall Unit, as part of the Colorado River Storage Project (CRSP) (US Department of the Interior, Bureau of Reclamation, Upper Colorado Region 2009).

Reclamation manages the CRSP to meet downstream flow requirements, hydroelectric power 8 needs, and provide for endangered fish and their habitat, along with other approved uses.

On average, streamflow over the Gunnison River Basin decreases over future multi-decadal periods. Of interest, one climate projection results in a streamflow projection in excess of $14800 \mathrm{MCM}$ (12.0 MAF) in the year 2030. This projection is made by the Canadian Centre for Climate Modeling and Analysis GCM (Flato and Boer, 2001) under an A1B emissions scenario, which, on average, is the more moderate emissions scenario considered in this study. The minimum annual flow projection is approximately $540 \mathrm{MCM}$ (0.44 MAF) in 2071. This minimum flow is a product of the GCM from the Institut Pierre Simon in Laplace, France (O et al., 2005); more intuitively, this projection falls under the A2 emissions scenario which describes, on average, a more aggressive warming trend. Figure 9 separates streamflow projections over the Gunnison River Basin by emission scenarios included in this study.

As shown in the right side of Fig. 7, the southern portion of the Gunnison River Basin exhibits the greatest percent reduction in projected streamflow from the calibration period. This area encompasses the southern portion of the Rocky Mountains. Previous work has shown that snowpack in this area has declined with warming trends over the Colorado River Basin and contribute decreased streamflow in the region (Mote et al., 2005; Mote, 2006).

\subsubsection{Green River Basin}

The Green River Basin contributes approximately $36 \%$ of the Upper Colorado River Basin's annual natural flow to the Colorado River. Reclamation manages two reservoirs, Fontenelle and Flaming Gorge, to regulate flow along the northern-most tributary to the Colorado River. Reclamation operates the Flaming Gorge reservoir to meet downstream water delivery and hydroelectric power needs. Like the Aspinall Unit, Flaming Gorge operations allow for Reclamation to protect and assist in the recovery of endangered fish within the Colorado River Basin.

Over the 30-yr calibration period, the average runoff from the Green River Basin is approximately 2380 MCM (1.93 MAF). Each of the 112 climate projections was used to force the NWS CBRFC RFS (Fig. 8). Over the model run period (1950-2099), average streamflow from the Green River Basin is approximately $2370 \mathrm{MCM}$ (1.92 MAF). On average, streamflow over the Green Basin increases slightly over future multi-decadal periods.

As shown in Fig. 11, much of the central portion of Green River Basin exhibits slightly increased streamflow when compared to the calibration period. This is somewhat consistent with results noted by Mote (2006). Mote (2006) describes increasing trends in SWE when using a regression describing SWE in terms of precipitation and temperature. The SNOW-17 model derives snowpack conditions in a similar fashion (Anderson, 2006). Under these climate conditions, increased model snowpack conditions would yield increased runoff throughout the basin.

\subsubsection{San Juan River Basin}

Since 1992, Reclamation has been working in collaboration with the San Juan River Basin Recovery Implementation Program to protect the Colorado pikeminnow and the razorback sucker and their respective habitat (US Fish and 


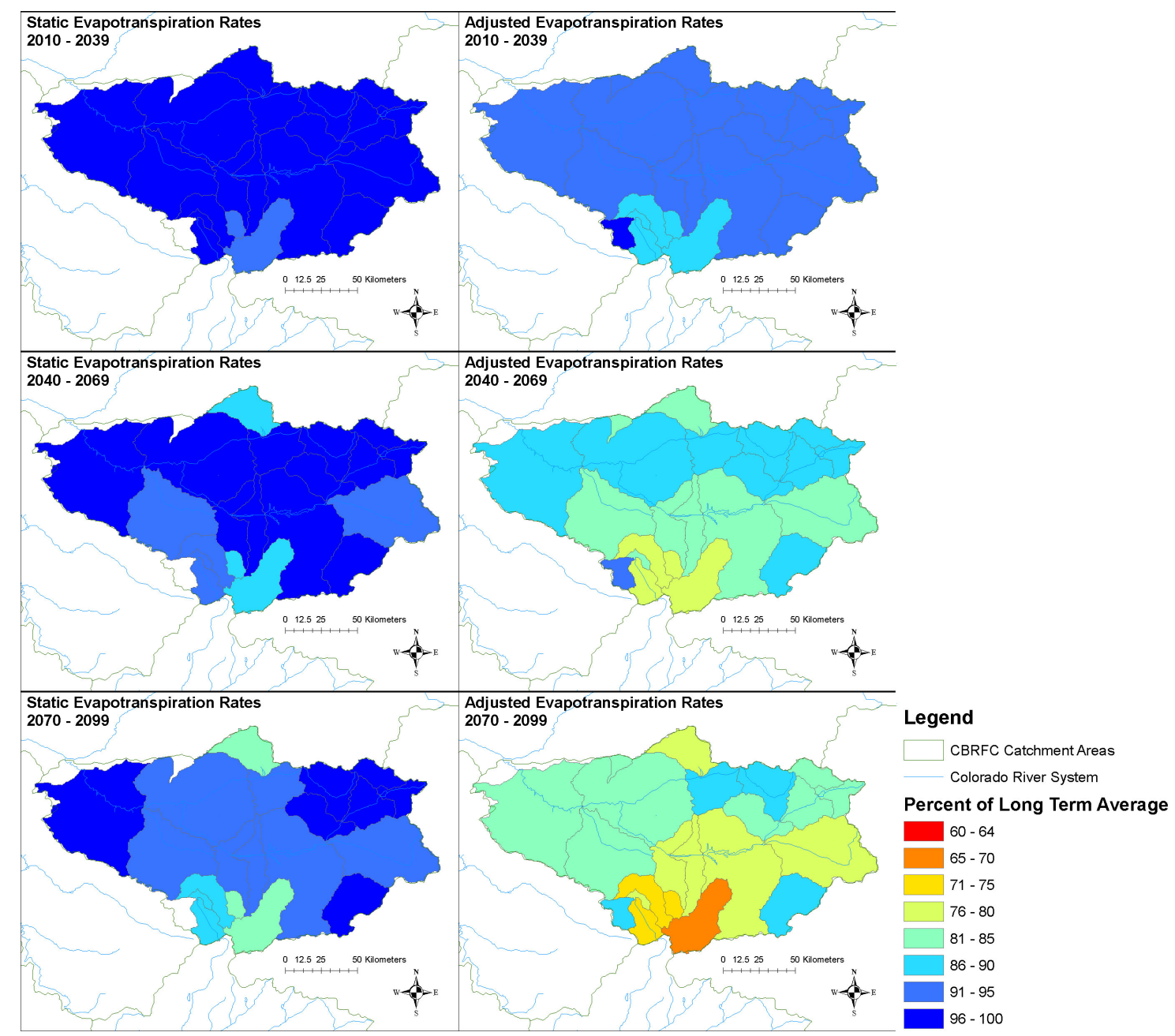

Fig. 7. Impact of adjusting evapotranspiration with changes in temperature at the catchment scale over the Gunnison River Basin. Panels on the left reflect average model output when evapotranspiration is not adjusted with temperature over the 2010-2039 time period (top left), the 2040-2069 time period (middle left), and the 2070-2099 time period (bottom left). Panels on the right reflect average model output when evapotranspiration is adjusted with temperature over the 2010-2039 time period (top right), the 2040-2069 time period (middle right), and the 2070-2099 time period (bottom right).

Wildlife Service, 2006). Reclamation operates the Vallecito and Navajo reservoirs within the San Juan River Basin to manage approximately $14 \%$ of the annual runoff to the Colorado River. Reservoirs within the San Juan River Basin are also part of the CRSP.

Over the 30-yr calibration period, the average runoff from the San Juan River Basin is approximately 2230 MCM (1.81 $\mathrm{MAF}$ ). Each of the 112 climate projections was used to force the NWS CBRFC RFS. Over the model run period (19502099), average streamflow from the San Juan River Basin is approximately $2060 \mathrm{MCM}$ (1.67 MAF) (Fig. 12).

On average, streamflow over the San Juan River Basin decreases over future multi-decadal periods. Of interest, one climate projection results in a streamflow projection in excess of $11100 \mathrm{MCM}$ (9.00 MAF) in the year 2030. Like the Gunnison River Basin, this projection is made by the Cana- dian Centre for Climate Modeling and Analysis GCM (Flato and Boer, 2001) under an A1B emissions scenario. The minimum annual flow projection is approximately $123 \mathrm{MCM}$ (0.10 MAF) in 2091. This minimum flow is also a product of the GCM from the Institut Pierre Simon in Laplace, France (O et al., 2005) under the A2 emissions scenario.

As shown in Fig. 13, the vast majority of the San Juan River Basin exhibits reduced streamflow when compared to the calibration period. Reduced streamflow in the region results in less flexibility in the management of Reclamation's reservoir system. With reduced flows, it is more difficult for Reclamation to manage reservoir releases to protect endangered fish in the area, particularly as it relates to the regulation of river temperatures and the protection of habitat area. 
a) Projected Unregulated Streamflow - Gunnison River Basin

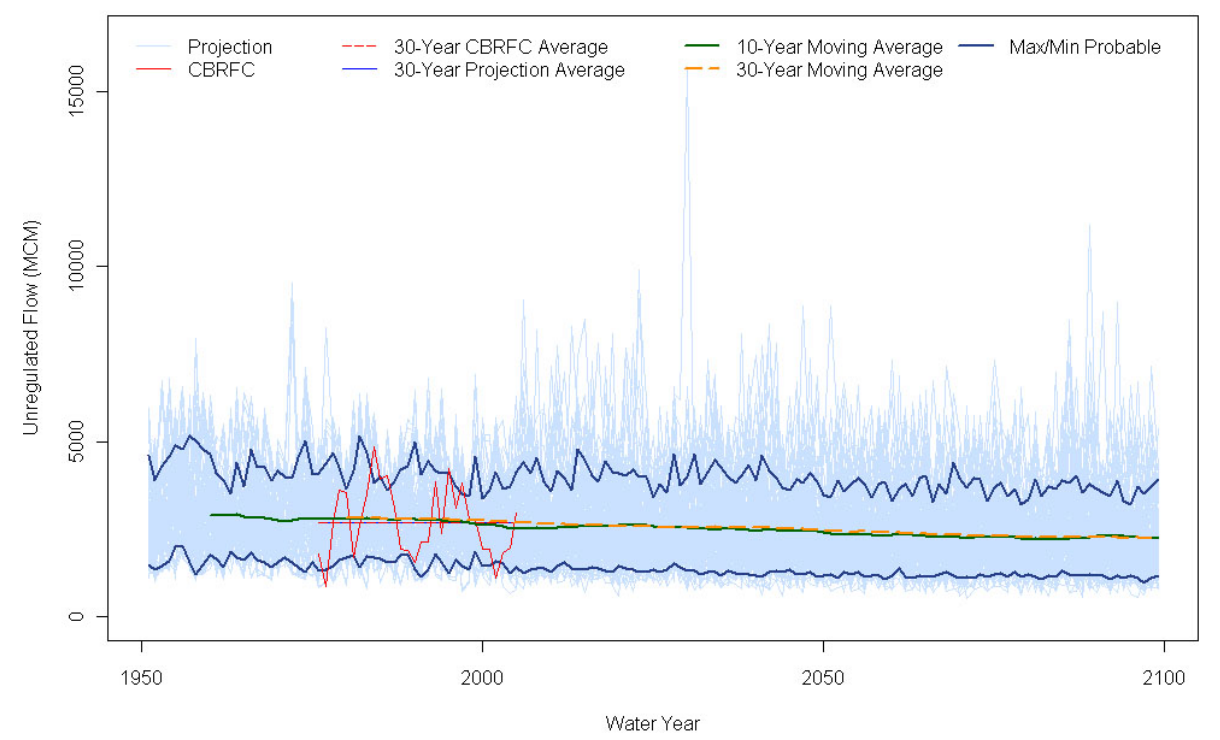

b)

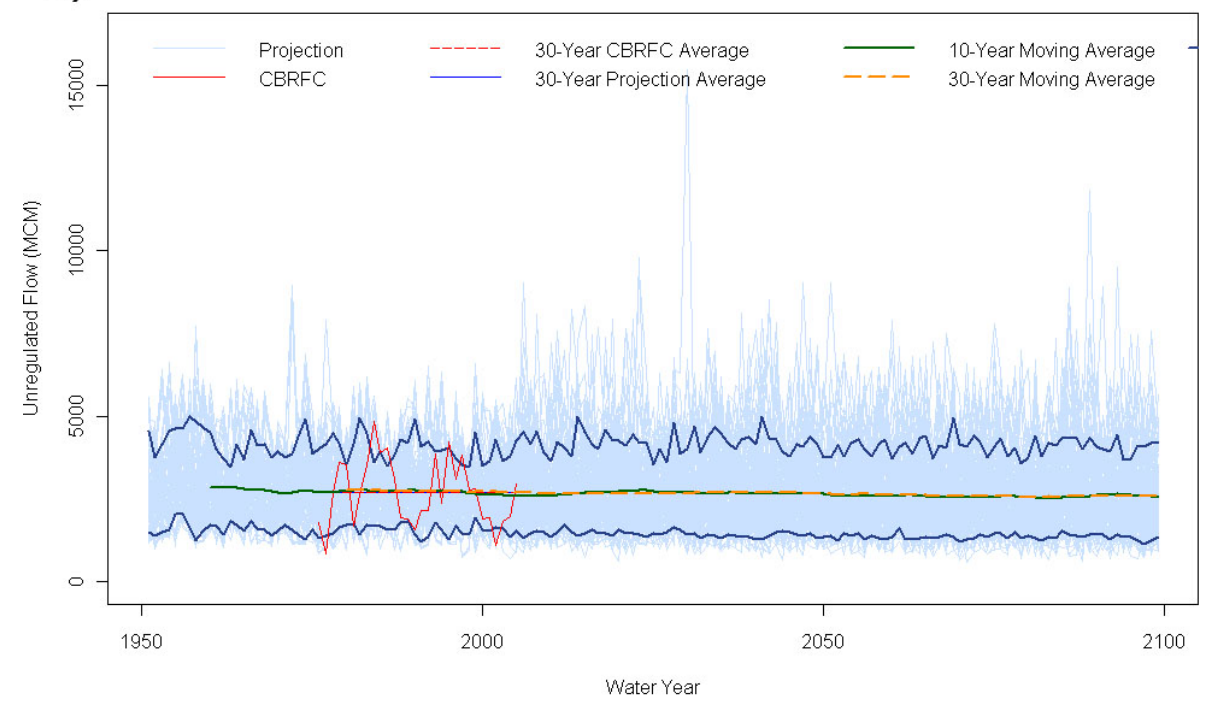

Fig. 8. Annual water year streamflow projections from each of the 112 climate projections over the Gunnison River Basin with (a) evapotranspiration changes with temperature considered and (b) static evapotranspiration rates considered. Results from the CBRFC's calibrated model are included as well as long-term averages. The blue lines in bold indicate the Maximum and Minimum Probable flows, defined by the CBRFC as the $10 \%$ exceedance and $90 \%$ exceedance values, respectively.

\section{Stationarity in projected streamflow forecasts}

The definition of stationarity, particularly with regards to climate change, is often under debate (e.g., Matter et al., 2010; Milly et al., 2008; Raff et al., 2009; Villarini et al., 2009; Wilby et al., 1999). The Kolmogorov-Smirnov Test (KSTest) is a nonparametric test for determining if the distributions of two samples are the same. The KS-Test compares empirical distributions of two sample sets of data and determining the maximum distance between the two sets of data (DeGroot, 1975; Georgakakos, 2003). This maximum dis- tance is a value from which the hypothesis that the underlying distribution is the same for both samples may be rejected if the value of the maximum distance exceeds a critical value defined by the size of the samples. The KS-Test has been used to compare ensemble streamflow projections between lumped and distributed hydrologic models (Carpenter and Georgakakos, 2006) as well as detecting changes in the probability distributions associated with precipitation and streamflow events (Wang et al., 2008). In this study, the KS-Test is utilized to compare probability distributions of 


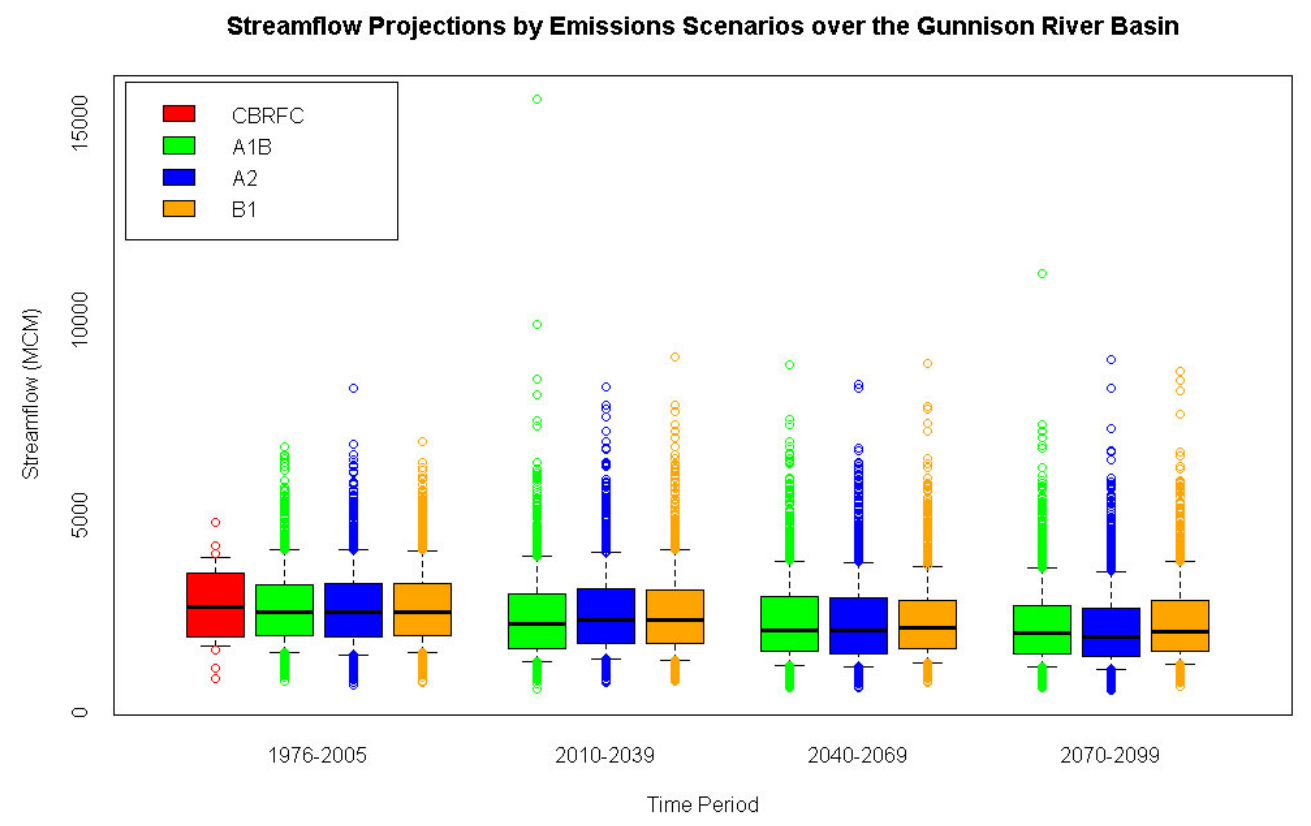

Fig. 9. Streamflow projections over the Gunnison River Basin separated by emissions scenarios and by climatology used by the CBRFC.

multi-decadal streamflow projections. Significantly different probability distributions are indicative of non-stationary behavior.

\subsection{Gunnison River Basin results}

Summary statistics for streamflow projections over the Gunnison River Basin are presented in Table 3. While there is an appreciable change in summary statistics between multidecadal periods, these changes may be attributed to natural hydroclimatic variability within the Colorado River Basin as evidenced by tree-ring reconstructions over the region (e.g., Meko et al., 2007; Woodhouse and Lukas, 2006; Woodhouse et al., 2006). The cumulative distribution functions (CDF) of streamflow, regardless of emission scenario, tend to be close, though separation is more apparent over the time period spanning 2070-2099.

The KS-Test was first applied between streamflow projections derived by the CBRFC over the calibration period and streamflow projections derived using climate data from the 112 temporally downscaled BCSD dataset over the same period. As would be expected, the test statistic derived using the KS-Test was less than the critical test statistic. Thus, the null hypothesis that the data comes from the same distribution could not be rejected. When streamflow projections derived from the 112 temporally downscaled BCSD dataset were separated by emission scenario over the calibration period, the result was the same.

The KS-Test was then applied between streamflow projections derived by the CBRFC over the calibration period and streamflow projections derived using climate data from the 112 temporally downscaled BCSD dataset over the entire period from 2010 to 2099. In this case, the test statistic derived using the KS-Test was greater than the critical test statistic. Thus, the null hypothesis that the data comes from the same distribution could be rejected and may be indicative of nonstationary behavior.

The KS-Test was then applied between streamflow projections derived by the CBRFC over the calibration period and streamflow projections derived using climate data from the 112 temporally downscaled BCSD CMIP3 dataset over the period from 2010 to 2099 , separated by emissions scenario and multi-decadal period. For each emissions scenario and projected streamflow over the period spanning 2010 to 2039, the test statistic was less than the critical value and the null hypothesis could not be rejected. However, for each emissions scenario and projected streamflow over the period spanning either 2040 to 2069 or 2070 to 2099 , the null hypothesis could be rejected. Table 4 summarizes results of the KS-Tests performed over the Gunnison River Basin.

\subsection{Green River Basin results}

Unlike the Gunnison River Basin there is not an appreciable change in summary statistics between multi-decadal periods over the Green River Basin. There is less deviation from the 1976-2005 mean over each multi-decadal period than that observed over the Gunnison River Basin.

KS-Test results were developed in an identical fashion to those over the Gunnison River Basin. The results of each KS-Test indicated that the null hypothesis could not be rejected; that is, each multi-decadal period did not come from 


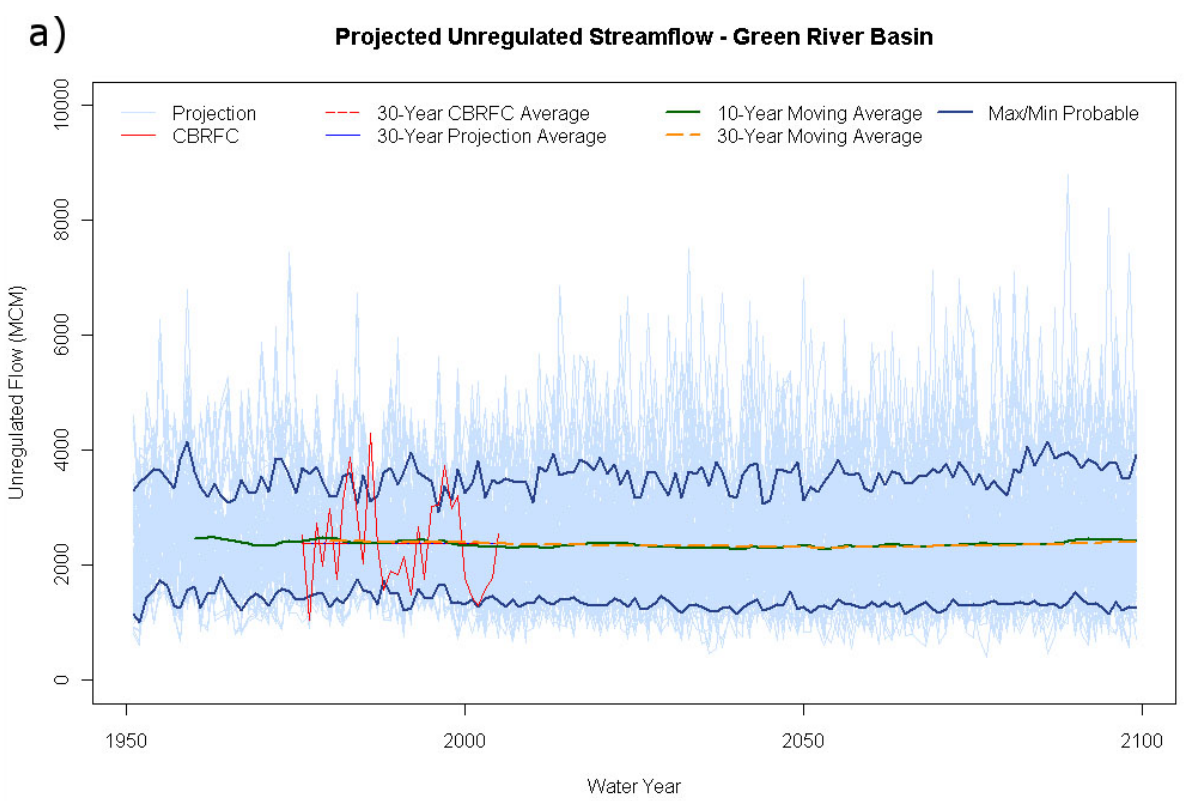

b)

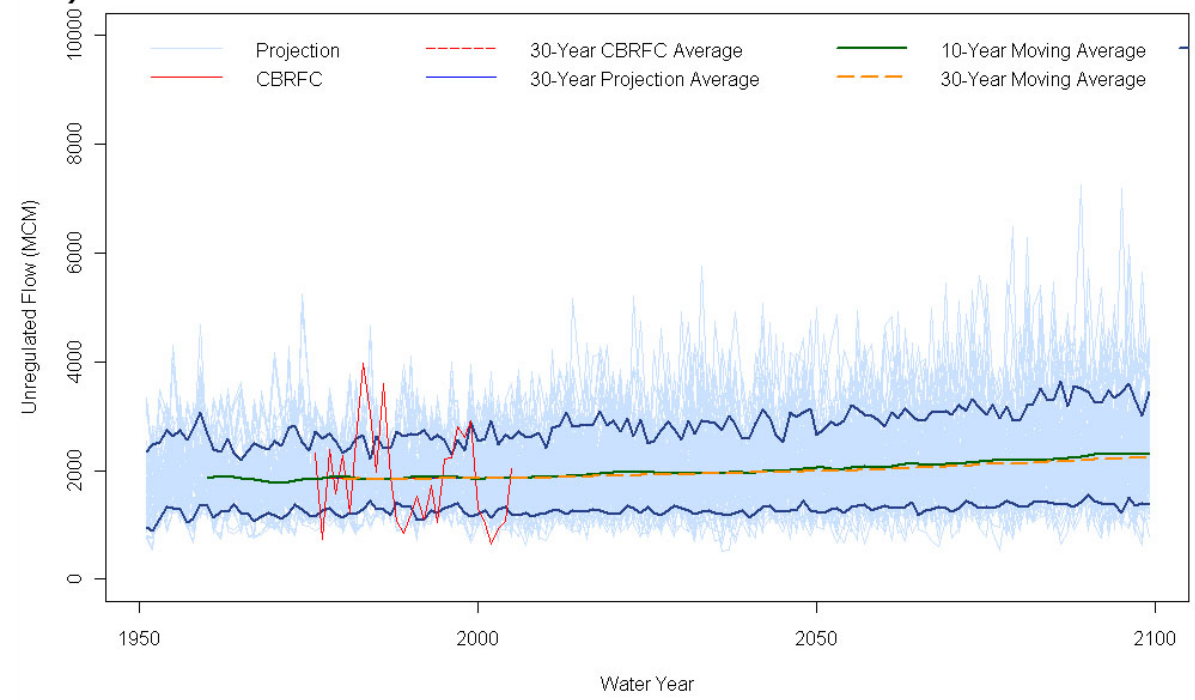

Fig. 10. Annual water year streamflow projections from each of the 112 climate projections over the Green River Basin with (a) evapotranspiration changes with temperature considered and (b) static evapotranspiration rates considered. Results from the CBRFC's calibrated model are included as well as long-term averages. The blue lines in bold indicate the Maximum and Minimum Probable flows, defined by the CBRFC as the $10 \%$ exceedance and $90 \%$ exceedance values, respectively.

a statistically different distribution. As a result, it is not possible to state that streamflow projections statistically exhibit nonstationary behavior. The topography of the Green River Basin is generally more mountainous and at higher elevations than those in the San Juan and Gunnison River Basins. As warming temperature impacts are more prevalent at lower elevations, projected climate over the Green River Basin may exhibit more stationary characteristics since climate change impacts are not as realized at higher elevations and latitudes (e.g., Mote et al., 2005; Mote, 2006). Table 4 summarizes the results of the KS-Tests over the Green River Basin.

\subsection{San Juan River Basin results}

Similar to the Gunnison River Basin, there is an appreciable change in summary statistics between multi-decadal periods over the San Juan River Basin. KS-Test results were developed in an identical fashion to those over the Gunnison and Green River Basin. Results over the San Juan River Basin were slightly different from those results derived over the Gunnison and Green River Basins. For the period spanning 2010-2039, the A1B emissions scenario exhibits a test statistic greater than the critical value such that the null hypothesis 


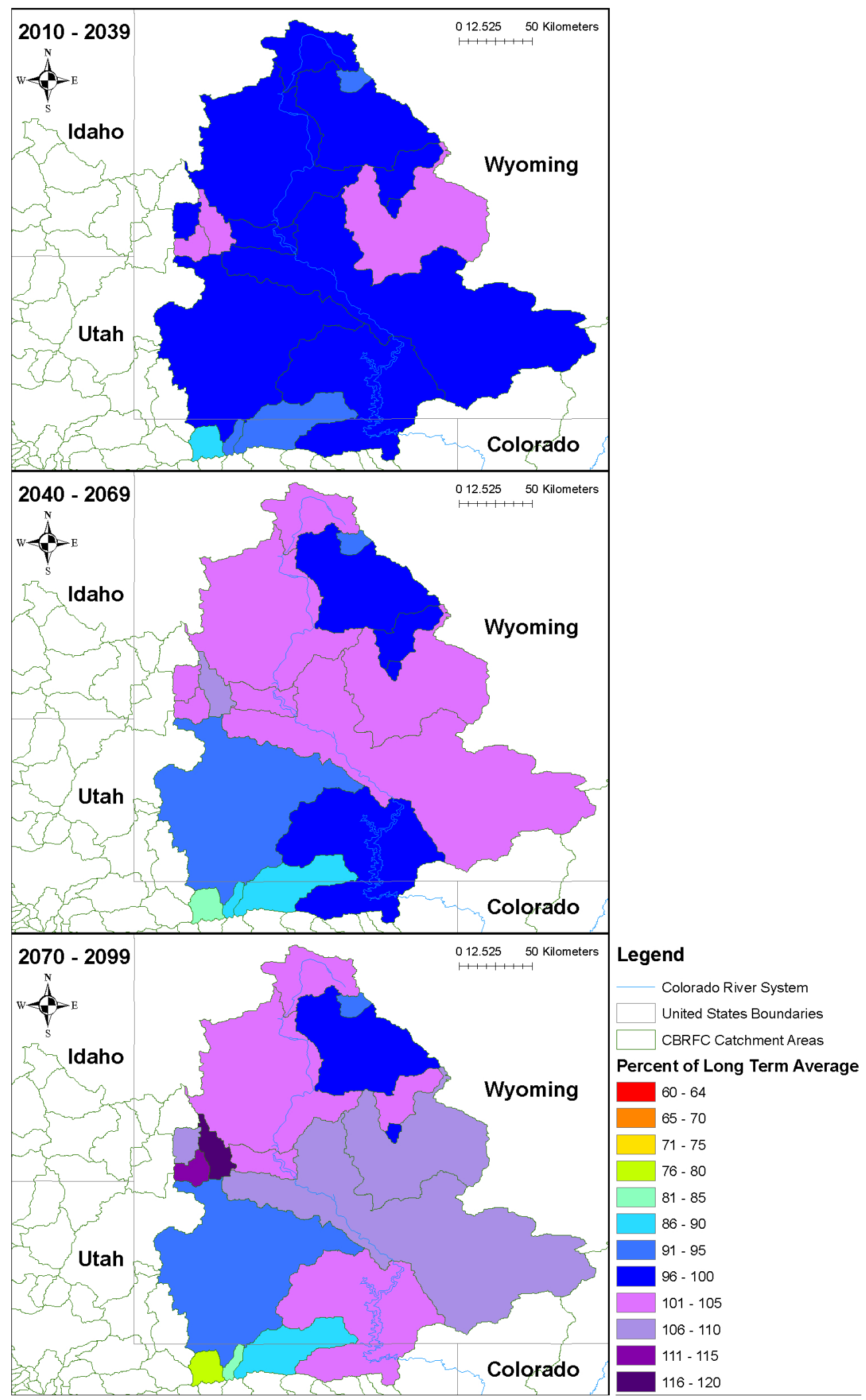

Fig. 11. Multi-decadal averages of streamflow projections over the Green River Basin. 
a) Projected Unregulated Streamflow - San Juan River Basin

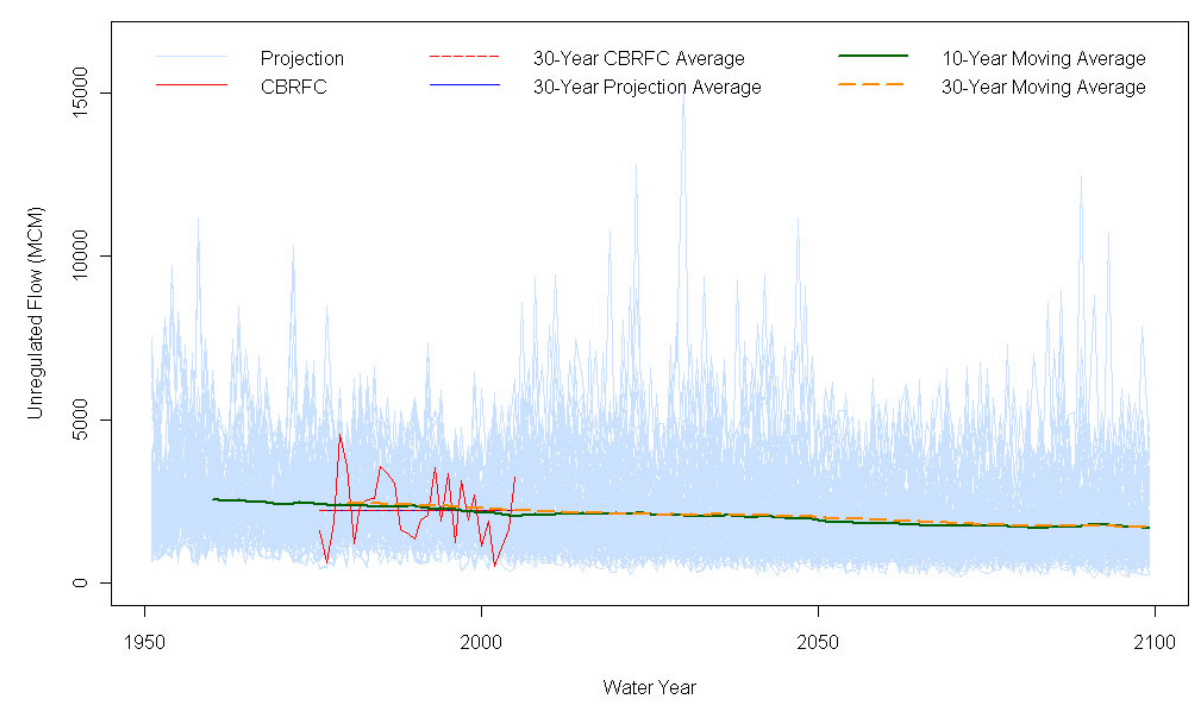

b)

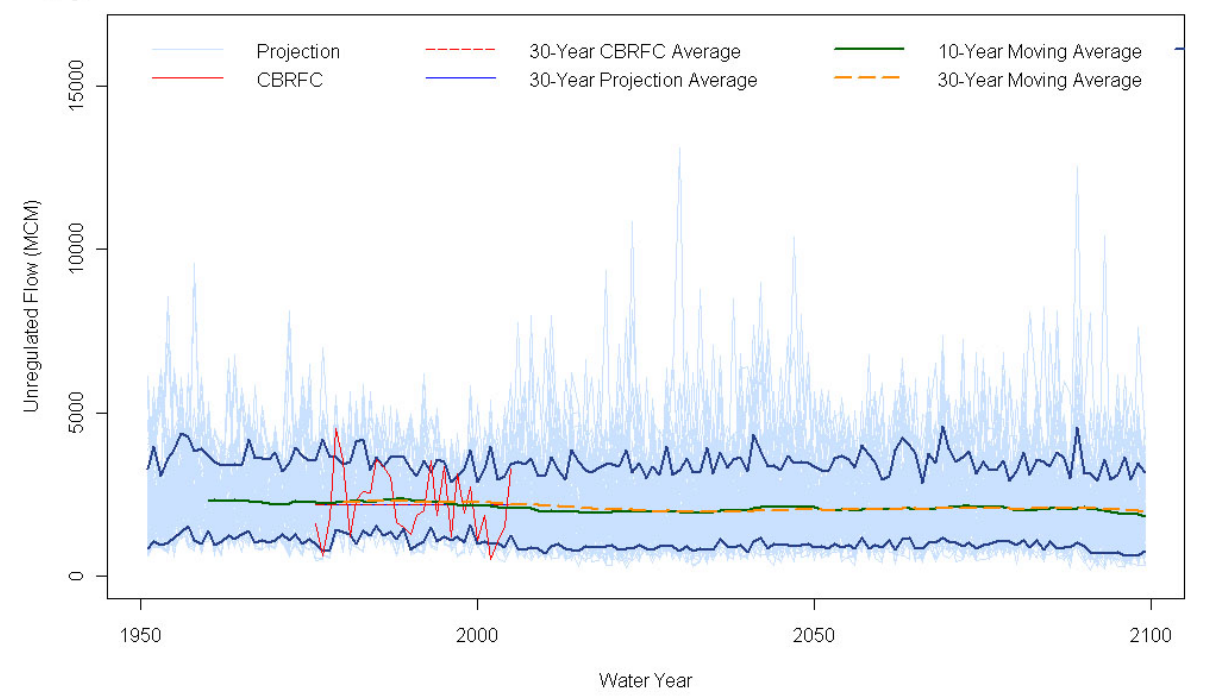

Fig. 12. Annual water year streamflow projections from each of the 112 climate projections over the San Juan River Basin with (a) evapotranspiration changes with temperature considered and (b) static evapotranspiration rates considered. Results from the CBRFC's calibrated model are included as well as long-term averages. The blue lines in bold indicate the Maximum and Minimum Probable flows, defined by the CBRFC as the $10 \%$ exceedance and $90 \%$ exceedance values, respectively.

could be rejected. Like the Gunnison River Basin, all emissions scenarios and projected streamflow spanning the period over 2040 to 2099, the test statistic was greater than the critical value and the null hypothesis could be rejected. Other KS-Test results were qualitatively identical with those observed over the Gunnison River Basin. Overall, the topography of the San Juan River Basin is at lower elevations than those in the Green and Gunnison River Basins. As warming temperature impacts are more prevalent at lower elevations, projected climate over the San Juan River Basin may exhibit nonstationary characteristics sooner than those projected in the Green and Gunnison River Basins. Table 4 summarizes results of the KS-Tests performed over the San Juan River Basin.

\section{Discussion}

In this study, a methodology for incorporating BCSD CMIP3 climate data into a hydrologic streamflow forecasting model was developed. This methodology utilized data from large scale GCMs that had been bias corrected and spatially 


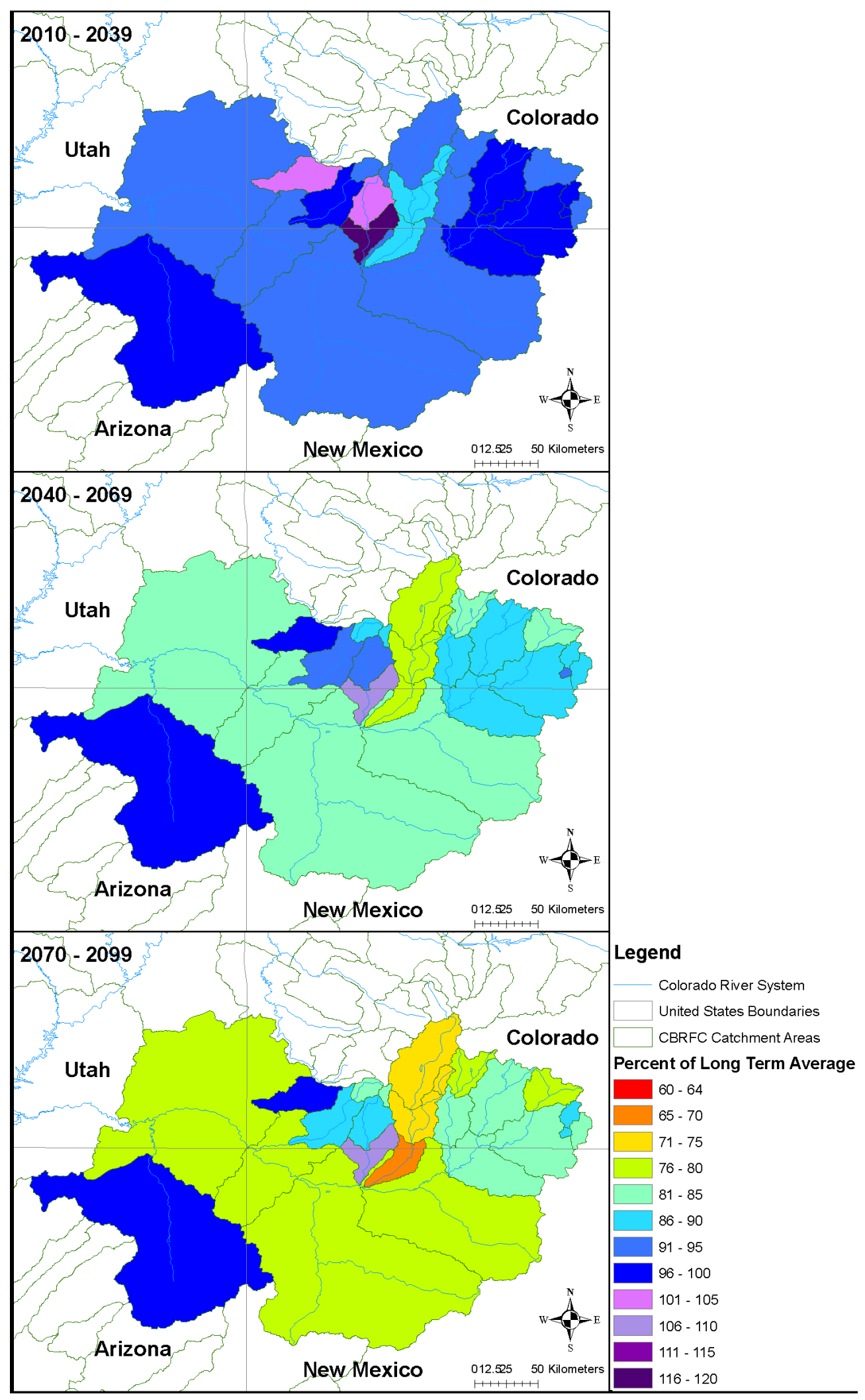

Fig. 13. Multi-decadal averages of streamflow projections over the San Juan River Basin. 
Table 3. Gunnison River Basin summary statistics.

\begin{tabular}{|c|c|c|c|c|c|c|c|c|c|c|c|c|}
\hline \multicolumn{13}{|c|}{ Summary Statistics of Streamflow Projections Over the Gunnison River Basin (MCM) } \\
\hline \multirow[b]{2}{*}{ Statistic } & \multicolumn{3}{|c|}{ 1976-2005 } & \multicolumn{3}{|c|}{ 2010-2039 } & \multicolumn{3}{|c|}{ 2040-2069 } & \multicolumn{3}{|c|}{ 2070-2099 } \\
\hline & $\mathrm{A} 2$ & B1 & A1B & $\mathrm{A} 2$ & B1 & A1B & $\mathrm{A} 2$ & B1 & A1B & A2 & B1 & A1B \\
\hline Min & 670 & 750 & 780 & 750 & 790 & 580 & 600 & 750 & 630 & 530 & 650 & 620 \\
\hline 1st Quartile & 1920 & 1940 & 1940 & 1750 & 1750 & 1620 & 1490 & 1600 & 1540 & 1410 & 1550 & 1490 \\
\hline Median & 2540 & 2570 & 2540 & 2360 & 2360 & 2260 & 2100 & 2130 & 2090 & 1900 & 2060 & 2020 \\
\hline Mean & 2690 & 2690 & 2690 & 2590 & 2580 & 2480 & 2330 & 2370 & 2360 & 2170 & 2340 & 2250 \\
\hline 3rd Quartile & 3270 & 3280 & 3240 & 3160 & 3120 & 3020 & 2900 & 2840 & 2960 & 2660 & 2850 & 2730 \\
\hline $\operatorname{Max}$ & 8260 & 6910 & 6770 & 8290 & 9080 & 15630 & 8380 & 8880 & 8870 & 8990 & 8700 & 11180 \\
\hline
\end{tabular}

Table 4. The following table is a summary of results from the KS Test applied in this study. Shaded boxes indicate time periods and emissions scenarios that were different from the calibration period (1976-2005) with statistical significance (greater than or equal to the $95 \%$ confidence interval). Unshaded boxes indicate that no inference could be made with statistical significance.

\begin{tabular}{|c|c|c|c|c|c|c|c|c|}
\hline \multirow[t]{2}{*}{$\begin{array}{l}\text { Time Period/ } \\
\text { Emissions Scenario }\end{array}$} & \multicolumn{2}{|c|}{ Gunnison River Basin } & \multicolumn{3}{|c|}{ Green River Basin } & \multicolumn{3}{|c|}{ San Juan River Basin } \\
\hline & $\mathrm{A} 1 \mathrm{~B} \mid \mathrm{A} 2$ & B1 & A1B & $\mathrm{A} 2$ & B1 & A1B & $\mathrm{A} 2$ & B1 \\
\hline \multicolumn{9}{|l|}{ 1976-2005 } \\
\hline \multicolumn{9}{|l|}{ 2010-2039 } \\
\hline \multicolumn{9}{|l|}{ 2040-2069 } \\
\hline 2070-2099 & & & & & & & & \\
\hline
\end{tabular}

downscaled such that the data would be useful in regional hydrologic studies. This study also proposes and incorporates a methodology to integrate impacts to evapotranspiration under changing climate conditions, as there has been limited research addressing this topic. This research further represents a methodology and progress towards the ability to incorporate climate change projections into Reclamation's existing operations plans and river and reservoir management studies. Although this research considers a river basin where water resources are administered by a United States federal agency (Reclamation), the methodology here is applicable to any basin or watershed area, as well as any hydrologic model and climate data sets. While this research investigated changes to streamflow in response to projected changes in climate, specifically with respect to temperature, precipitation, and evapotranspiration demand, it is important to note that these are not the sole parameters that may be investigated when using a hydrologic model to project future water supply. Recent research has investigated the role of land cover and climatic change to basin hydrology (Cuo et al., 2009). By accounting for multiple emissions scenarios from multiple climate models, this study implicitly accounts for additional impacts to hydroclimatic variables due to climate change. Future research is necessary to assess the impacts of specific hydroclimatic variables to regional and global hydrology.

Evapotranspiration demand under changing climate conditions is not trivial in hydrologic modeling efforts or water resource management studies. A major contribution of this study is that by adjusting static evapotranspiration demand with temperature within a lumped model, catchment streamflow projections better reflect the potential impacts of climate change. The CBRFC currently adjusts evapotranspiration demand within the SAC-SMA model within the NWS RFS to calibrate the model to observed streamflow in the basin. This methodology highlights both the importance and uncertainty regarding evapotranspiration in hydrologic modeling studies. Evapotranspiration demand is a sensitive and important parameter that must be accounted for; however, due to limited observational data, it is often implicitly calculated through calibration efforts or as part of a mass balance formulation. Under changing climate conditions, this uncertainty increases. This study presents a progressive methodology through which changes to evapotranspiration demand may be addressed when dealing with uncertainty associated with climate change. Previous studies have presented progressive automated calibration schemes but do not address evapotranspiration demand (e.g., Hogue et al., 2000, 2006; 
Sorooshian et al., 1993). Regardless, under changing climate conditions, accurate estimates and measurements of evapotranspiration will become increasingly important.

Previous efforts to project streamflow under changing climate conditions over the Colorado River Basin have yielded a broad range of results. Many studies indicate that over the next 30 to $60 \mathrm{yr}$ (2040 through 2070) the Colorado River Basin may experience decreased runoff on the order of $6 \%$ to $20 \%$ (Christensen et al., 2004; Christensen and Lettenmaier, 2007; McCabe and Wolock, 2008; Milly et al., 2005); these studies have utilized a variety of models (most notably the VIC model), methodologies, and datasets. The results of this study support previous research efforts indicating a decrease in flow from the Colorado River Basin, as evidenced by decreased flow over the Gunnison and San Juan River Basins. Recent research has indicated the potential for increased flow and variability in the northern portion of Colorado River Basin and its surrounding area (e.g., Aziz et al., 2010; Barnett et al., 2010). Here, projections of streamflow over the Green River Basin indicate the potential for increased flow into the future, suggesting that drying may not be uniform or present over the entire Colorado River Basin. Spatial heterogeneity with respect to the magnitude and state (i.e., wet or dry) of streamflow conditions over the Colorado River Basin may present more complex challenges for water resource managers as the impacts of climate change are realized.

Future efforts may examine an improved methodology from that presented in this study. In particular, detailed assessment of the uncertainty associated with the projection of future flows may better quantify future ranges of projected streamflows. Here, a ratio method was employed as a post-bias correction term. This method has the advantage of not confining projected streamflows to the previous range of historical values which is important when investigating climate change impacts and nonstationary behavior; however, advanced statistical methods may be employed to decrease uncertainty and narrow the range associated with long-term projections of streamflow.

Under the definition of stationarity presented in Milly et al. (2008), lower latitude Colorado River Basin headwaters (i.e., the Gunnison and San Juan River Basins) investigated in this study will exhibit nonstationary characteristics with changing climate conditions. This is important to water resource managers, particularly in Reclamation, where past observations of streamflow are assumed to be representative of future conditions. Future study may investigate the presence on nonstationarity at the seasonal scale to determine potential shifts in the timing and magnitude of streamflow runoff under changing climate conditions.

Acknowledgements. The authors would like to acknowledge the staff of the CBRFC in Salt Lake City, Utah for allowing access to their datasets and models for use in this study.
The authors acknowledge the modeling groups, the Program for Climate Model Diagnosis and Intercomparison (PCMDI) and the WCRP's Working Group on Coupled Modeling (WGCM) for their roles in making available the WCRP CMIP3 multi-model dataset. Support of this dataset is provided by the Office of Science, US Department of Energy.

The research at University of Nevada, Las Vegas is supported by grants NSF EPS-0814372, NOAA NA070AR4310228, DOE DE-FG02-08ER64709, and DOE DE-EE-0000716.

Edited by: J. Freer

\section{References}

Anderson, E. A.: National Weather Service River Forecast System: Snow Accumulation and Ablation Model, National Oceanic and Atmospheric Administration, National Weather Service, Silver Springs, MD, 1973.

Anderson, E. A.: Snow Accumulation and Ablation Model SNOW-17, National Oceanic and Atmospheric Administration, National Weather Service, Silver Springs, MD, 2006.

Aziz, O. A., Tootle, G. A., Gray, S. T., and Piechota, T. C.: Identification of Pacific Ocean sea surface temperature influences of Upper Colorado River Basin snowpack, Water Resour. Res., 46, W07536, doi:10.1029/2009WR008053, 2010.

Balling Jr., R. C. and Goodrich, G. B.: Analysis of Drought Determinants for the Colorado River Basin, Climatic Change, 82, 179-194, dio:10.1007/s10584-006-9157-8, 2007.

Barnett, F. A., Gray, S. T., and Tootle, G. A.: Upper green river basin (United States) streamflow reconstructions, J. Hydrol. Eng., 15, 567-579, doi:10.1061/(ASCE)HE.19435584.0000213, 2010.

Barnett, T. P. and Pierce, D. W.: When Will Lake Mead Go Dry?, Water Resour. Res., 44, doi:10.1029/2007WR006704, 2008.

Barnett, T. P. and Pierce, D. W.: Sustainable Water Deliveries from the Colorado River in a Changing Climate, Proc. Natl. Acad. Sci. USA, 106, 7334-7338, W03201, doi:10.1073/pnas.0812762106, 2009.

Barsugli, J., Nowak, K., Rajagopalan, B., Prairie, J. R., and Harding, B.: Comment on "When Will Lake Mead Go Dry?", by Barnett, T. P. and Pierce, D. W., Water Resour. Res., 45, W09601, doi:10.1029/2008WR007627, 2009.

Brekke, L. and Prairie, J.: Long-Term Planning Hydrology based on Various Blends of Instrumental Records, Paleoclimate, and Projected Climate Information, US Department of the Interior, Bureau of Reclamation, Denver, CO, 2009.

Brekke, L. D., Dettinger, M. D., Maurer, E. P., and Anderson, M.: Significance of Model Credibility in Estimating Climate Projection Distributions for Regional Hydroclimatological Risk Assessments, Climatic Change, 89, 371-394, 10.1007/s10584-0079388-3, 2008.

Burnash, R. J., Ferral, R. L., and McQuire, R. A.: A Generalized Streamflow Simulation System, in: Conceptual Modeling for Digital Computers, USA National Weather Service, 1973.

Carpenter, T. M. and Georgakakos, K. P.: Intercomparison of Lumped Versus Distributed Hydrologic Model Ensemble Simulations on Operational Forecast Scales, J. Hydrol., 329, 174-185, doi:10.1016/j.jhydrol.2006.02.013, 2006. 
Cayan, D. R., Maurer, E. P., Dettinger, M. D., Tyree, M., and Hayhoe, K.: Climate Change Scenarios for the California Region, Climatic. Change, 1-22, doi:10.1007/s10584-007-9377-6, 2007.

Christensen, N. S., Wood, A. W., Voisin, N., Lettenmaier, D. P., and Palmer, R. N.: The Effects of Climate Change on the Hydrology and Water Resources of the Colorado River basin, Climatic Change, 62, 337-363, doi:10.1023/B:CLIM.0000013684.13621.1f, 2004.

Christensen, N. S. and Lettenmaier, D. P.: A multimodel ensemble approach to assessment of climate change impacts on the hydrology and water resources of the Colorado River Basin, Hydrol. Earth Syst. Sci., 11, 1417-1434, doi:10.5194/hess-11-14172007, 2007.

Cuo, L., Lettenmaier, D. P., Alberti, M., and Richey, J. E.: Effects of a century of land cover and climate change on the hydrology of the Puget Sound basin, Hydrol. Process., 23, 907-933, doi:10.1002/hyp.7228, 2009.

DeGroot, M. H.: Probability and Statistics, Addison-Wesley Pub. Co., Reading, Massachusetts, 1975.

Fassnacht, S. R.: Upper Versus Lower Colorado River Sub-Basin Streamflow: Characteristics, Runoff Estimation and Model Simulation, Hydrol. Process., 20, 2187-2205, doi:10.1002/hyp.6202, 2006.

Flato, G. M. and Boer, G. J.: Warming Asymmetry in Climate Change Simulations, Geophys. Res. Lett., 28, 195-198, doi:10.1029/2000GL012121, 2001.

Georgakakos, K. P.: Probabilistic Climate-Model Diagnostics for Hydrologic and Water Resources Impact Studies, J. Hydrometeorol., 4, 92-105, doi:10.1175/15257541(2003)004<0092:PCMDFH > 2.0.CO;2, 2003.

Hamlet, A. F. and Lettenmaier, D. P.: Effects of 20th Century Warming and Climate Variability on Flood Risk in the Western US, Water Resour. Res., 43, W06427, doi:10.1029/2006WR005099, 2007.

Hamlet, A. F., Mote, P. W., Clark, M. P., and Lettenmaier, D. P.: Effects of Temperature and Precipitation Variability on Snowpack Trends in the Western United States, J. Clim., 18, 4545-4561, doi:10.1175/JCLI3538.1, 2005.

Hamlet, A. F., Mote, P. W., Clark, M. P., and Lettenmaier, D. P.: Twentieth-Century Trends in Runoff, Evapotranspiration, and Soil Moisture in the Western United States, J. Clim., 20, 14681486, doi:10.1175/JCLI4051.1, 2007.

Hayhoe, K., Cayan, D., Field, C. B., Frumhoff, P. C., Maurer, E. P., Miller, N. L., Moser, S. C., Schneider, S. H., Cahill, K. N., Cleland, E. E., Dale, L., Drapek, R., Hanemann, R. M., Kalkstein, L. S., Lenihan, J., Lunch, C. K., Neilson, R. P., Sheridan, S. C., and Verville, J. H.: Emissions Pathways, Climate Change, and Impacts on California, Proc. Natl. Acad. Sci. USA, 101, 1242212427, doi:10.1073/pnas.0404500101, 2004.

Hayhoe, K., Wake, C. P., Huntington, T. G., Luo, L., Schwartz, M. D., Sheffield, J., Wood, E., Anderson, B., Bradbury, J., DeGaetano, A., Troy, T. J., and Wolfe, D.: Past and Future Changes in Climate and Hydrological Indicators in the US Northeast, Clim. Dynam., 28, 381-407, doi:10.1007/s00382-006-0187-8, 2007.

Hidalgo, H. G., Das, T., Dettinger, M. D., Cayan, D. R., Pierce, D. W., Barnett, T. P., Bala, G., Mirin, A., Wood, A. W., Bonfils, C., Santer, B. D., and Nozawa, T.: Detection and Attribution of Streamflow Timing Changes to Climate Change in the Western United States, J. Clim., 22, 3838-3855,
doi:10.1175/2009JCLI2470.1, 2009.

Hoerling, M. and Eischeid, J.: Past Peak Water in the Southwest, Southwest Hydrology, 6, 18-35, 2007.

Hogue, T. S., Sorooshian, S., Gupta, H., Holz, A., and Braatz, D.: A Multistep Automatic Calibration Scheme for River Forecasting Models, J. Hydrometeorol., 1, 524-542, 2000.

Hogue, T. S., Gupta, H., and Sorooshian, S.: A 'User-Friendly' Approach to Parameter Estimation in Hydrologic Models, J. Hydrol., 320, 202-217, doi:10.1016/j.jhydrol.2005.07.009, 2006.

Hurkmans, R. T. W. L., De Moel, H., Aerts, J. C. J. H., and Troch, P. A.: Water Balance Versus Land Surface Model in the Simulation of Rhine River Discharges, Water Resour. Res., 44, W01418, doi:10.1029/2007WR006168, 2008.

Hurkmans, R. T. W. L., Terink, W., Uijlenhoet, R., Moors, E. J., Troch, P. A., and Verburg, P. H.: Effects of Land Use Changes on Streamflow Generation in the Rhine Basin, Water Resour. Res., 45, W06405, doi:10.1029/2008WR007574, 2009.

Kalra, A., Piechota, T. C., Davies, R., and Tootle, G. A.: Changes in US Streamflow and Western U.S. Snowpack, J. Hydrol. Eng., 13, 156-163, doi:10.1061/(ASCE)1084-0699(2008)13:3(156), 2008.

Lakshmi, V. and Wood, E. F.: Diurnal Cycles of Evaporation Using a Two-Layer Hydrological Model, J. Hydrol., 204, 37-51, doi:10.1016/S0022-1694(97)00108-X, 1998.

Matter, M. A., Garcia, L. A., Fontane, D. G., and Bledsoe, B.: Characterizing Hydroclimatic Variability in Tributaries of the Upper Colorado River Basin-WY1911-2001, J. Hydrol., 380, 260-276, doi:10.1016/j.jhydrol.2009.10.040, 2010.

Maurer, E. P.: Uncertainty in Hydrologic Impacts of Climate Change in the Sierra Nevada, California, Under Two Emissions Scenarios, Climatic Change, 82, 309-325, doi:10.1007/s10584006-9180-9, 2007.

Maurer, E. P. and Duffy, P. B.: Uncertainty in Projections of Streamflow Changes Due to Climate Change in California, Geophys. Res. Lett., 32, 1-5, doi:10.1029/2004GL021462, 2005.

Maurer, E. P., Brekke, L., Pruitt, T. and Duffy, P. B.: FineResolution Climate Projections Enhance Regional Climate Change Impact Studies, Eos, 88, 2007.

McCabe Jr., G. J.: Relationships Between Atmospheric Circulation and Snowpack in the Gunnison River Basin, Colorado, J. Hydrol., 157, 157-175, 1994.

McCabe, G. J. and Wolock, D. M.: Joint Variability of Global Runoff and Global Sea Surface Temperatures, J. Hydrometeorol., 9, 816-824, doi:10.1175/2008JHM943.1, 2008.

Meehl, G. A., Covey, C., Delworth, T., Latif, M., McAvaney, B., Mitchell, J. F. B., Stouffer, R. J., and Taylor, K. E.: The WCRP CMIP3 Multimodel Dataset: A New Era in Climatic Change Research, B. Am. Meteorol. Soc., 88, 1383-1394, doi:10.1175/BAMS-88-9-1383, 2007.

Meko, D. M., Woodhouse, C. A., Baisan, C. A., Knight, T., Lucas, J. J., Hughes, M. K., and Salzer, M. W.: Medieval Drought in the Upper Colorado River Basin, Geophys. Res. Lett., 34, L10705, doi:10.1029/2007GL029988, 2007.

Miller, W. P. and Piechota, T. C.: Regional Analysis of Trend and Step Changes Observed in Hydroclimatic Variables Around the Colorado River Basin, J. Hydrometeorol., 9, 1020-1034, doi:10.1175/2008JHM988.1, 2008.

Milly, P. C. D., Dunne, K. A., and Vecchia, A. V.: Global Pattern of Trends in Streamflow and Water Availability in a Changing 
Climate, Nature, 438, 347-350, doi:10.1038/nature04312, 2005.

Milly, P. C. D., Betancourt, J., Falkenmark, M., Hirsch, R. M., Kundzewicz, Z. W., Lettenmaier, D. P., and Stouffer, R. J.: Climate Change: Stationarity is Dead: Whither Water Management?, Science, 319, 573-574, doi:10.1126/science.1151915, 2008.

Mote, P. W.: Climate-Driven Variability and Trends in Mountain Snowpack in Western North America, J. Clim., 19, 6209-6220, doi:10.1175/JCLI3971.1, 2006.

Mote, P. W., Hamlet, A. F., Clark, M. P., and Lettenmaier, D. P.: Declining Mountain Snowpack in Western North America, B. Am. Meteorol. Soc., 86, 39-49, doi:10.1175/BAMS-86-1-39, 2005.

Nakićenović, N. and Intergovernmental Panel on Climate Change: Special Report on Emissions Scenarios: A Special Report of Working Group III of the Intergovernmental Panel on Climate Change, Cambridge University Press, Cambridge, 2000.

National Oceanic and Atmospheric Administration, National Weather Service: Introduction to the National Weather Service River Forecast System (NWSRFS) User Manual, National Oceanic and Atmospheric Administration, Silver Springs, MD, 2005.

Nijssen, B., Lettenmaier, D. P., Liang, X., Wetzel, S. W., and Wood, E. F.: Streamflow simulation for continental-scale river basins, Water Resour. Res., 33, 711-724, 1997.

O, M., Braconnot, P., Bellier, J., Benshila, R., Bony, S., Brockman, P., Cadulle, P., Caubel, A., Denvil, S., Dufresne, J. L., Fairhead, L., Filiberti, M., Fichefet, T., Friedlingstein, P., Grandpeix, J., Hourdin, F., Krinner, G., Levy, C., Musat, I., Talandier, C., and IPSL Global Modeling Group: The New IPSL Climate System Model: IPSL-CM4, Institut Pierre Simon Laplace des Sciences de l'Environnement Global, France, 2005.

Payne, J. T., Wood, A. W., Hamlet, A. F., Palmer, R. N., and Lettenmaier, D. P.: Mitigating the Effects of Climate Change on the Water Resources of the Columbia River Basin, Climatic Change, 62, 233-256, doi:10.1023/B:CLIM.0000013694.18154.d6, 2004.

Raff, D. A., Pruitt, T., and Brekke, L. D.: A framework for assessing flood frequency based on climate projection information, Hydrol. Earth Syst. Sci., 13, 2119-2136, doi:10.5194/hess-132119-2009, 2009.

Rajagopalan, B., Nowak, K., Prairie, J., Hoerling, M., Harding, B., Barsugli, J., Ray, A., and Udall, B.: Water Supply Risk on the Colorado River: Can Management Mitigate?, Water Resour. Res., 45, W08201, doi:10.1029/2008WR007652, 2009.

Regonda, S. K., Rajagopalan, B., Clark, M., and Pitlick, J.: Seasonal Cycle Shifts in Hydroclimatology Over the Western United States, J. Clim., 18, 372-384, doi:10.1175/JCLI-3272.1, 2005.

Smith, G.: Empirical Derivation of 6-Hour Temperature Values from Daily Minimum and Maximum Temperature Values, 2009.

Solomon, S. and Intergovernmental Panel on Climate Change, Working Group I (Eds.): Climate Change 2007: The Physical Science Basis: Contribution of Working Group I to the Fourth Assessment Report of the Intergovernmental Panel on Climate Change, Cambridge University Press, Cambridge; New York, 2007.

Sorooshian, S., Duan, Q., and Gupta, V. K.: Calibration of RainfallRunoff Models: Application of Global Optimization to the Sacramento Soil Moisture Accounting Model, Water Resour. Res., 29, 1185-1194, doi:10.1029/92WR02617, 1993.
Timilsena, J. and Piechota, T.: Regionalization and Reconstruction of Snow Water Equivalent in the Upper Colorado River Basin, J. Hydrol., 352, 94-106, doi:10.1016/j.jhydrol.2007.12.024, 2008.

Timilsena, J., Piechota, T. C., Hidalgo, H., and Tootle, G.: Five Hundred Years of Hydrological Drought in the Upper Colorado River Basin, J. Am. Water Resour. Assoc., 43, 798-812, doi:10.1111/j.1752-1688.2007.00064.x, 2007.

Tootle, G. A. and Piechota, T. C.: Drought and the 2002-2003 El Niño in the Southwest US, in: World Water and Environmental Resources Congress 2003, Philadelphia, PA, 23 June 2003 through 26 June 2003.

US Department of the Interior, Bureau of Reclamation, Upper Colorado Region: Final Environmental Impact Statement, Navajo Reservoir Operations, Navajo Unit - San Juan River, New Mexico, Colorado, Unit, US Department of the Interior, Grand Junction - Durango, Colorado, 2006.

US Department of the Interior, Bureau of Reclamation, Lower Colorado Region: Colorado River Basin Water Supply and Demand Study, US Bureau of Reclamation, Lower Colorado Region, Boulder City, NV, 2009.

US Department of the Interior, Bureau of Reclamation, Upper Colorado Region: Draft Environmental Impact Statement, Aspinall Unit Operations, Aspinall Unit - Colorado River Storage Project, Gunnison River, Colorado, United States Department of the Interior, Grand Junction, Colorado, 2009.

US Fish and Wildlife Service: San Juan River Basin Recovery Implementation Program, San Juan River Basin Recovery Implementation Program Biology Committee and Researchers, 2006.

VanRheenen, N. T., Wood, A. W., Palmer, R. N., and Lettenmaier, D. P.: Potential Implications of PCM Climate Change Scenarios for Sacramento-San Joaquin River Basin Hydrology and Water Resources, Climatic. Change, 62, 257-281, doi:10.1023/B:CLIM.0000013686.97342.55, 2004.

Villarini, G., Serinaldi, F., Smith, J. A., and Krajewski, W. F.: On the Stationarity of Annual Flood Peaks in the Continental United States During the 20th Century, Water Resour. Res., 45, W08417, doi:10.1029/2008WR007645, 2009.

Wang, W., Chen, X., Shi, P., and van Gelder, P. H. A. J. M.: Detecting changes in extreme precipitation and extreme streamflow in the Dongjiang River Basin in southern China, Hydrol. Earth Syst. Sci., 12, 207-221, doi:10.5194/hess-12-207-2008, 2008.

Wilby, R. L., Hay, L. E., and Leavesley, G. H.: A Comparison of Downscaled and Raw GCM Output: Implications for Climate Change Scenarios in the San Juan River Basin, Colorado, J. Hydrol., 225, 67-91, doi:10.1016/S0022-1694(99)00136-5, 1999.

Wood, A. W., Leung, L. R., Sridhar, V., and Lettenmaier, D. P.: Hydrologic Implications of Dynamical and Statistical Approaches to Downscaling Climate Model Outputs, Climatic Change, 62, 189-216, doi:10.1023/B:CLIM.0000013685.99609.9e, 2004.

Woodhouse, C. A. and Lukas, J. J.: Multi-Century TreeRing Reconstructions of Colorado Streamflow for Water Resource Planning, Climatic Change, 78, 293-315, W05415, doi:10.1007/s10584-006-9055-0, 2006.

Woodhouse, C. A., Gray, S. T. and Meko, D. M.: Updated Streamflow Reconstructions for the Upper Colorado River Basin, Water Resour. Res., 42, doi:10.1029/2005WR004455, 2006. 